\title{
Slave Trade Dynamics in Abbasid Egypt: The Papyrological Evidence
}

\author{
Jelle Bruning \\ Leiden University, Leiden, The Netherlands \\ j.bruning@hum.leidenuniv.nl
}

\begin{abstract}
This article discusses the commercial, socio-economic and legal dynamics of slave trading in Egypt on the basis of papyri from the AH third-fourth/ninth-tenth centuries CE. Particular focus is given to the activities of slavers, the networks of professional slave traders, the socio-economics of slave acquisition, and commercial dynamics at slave markets. Much of the discussion draws on the contents of five contemporary papyrus documents that are presented, translated and annotated in the appendix.
\end{abstract}

\section{Keywords}

slavery - trade - Egypt - Arabic papyri - third-fourth/ninth-tenth centuries

\section{$1 \quad$ Introduction}

Our understanding of slavery in the first four centuries of Islam has increased greatly in the last two decades. Not only have scholars asked new questions from the better-known literary sources dating from the AH second/eighth century CE and later, ${ }^{1}$ but archaeological, numismatic and papyrological studies have now entered the discussion on slavery among early Muslim communities. These new disciplinary approaches deeply enrich the often disparate

1 E.g., Ali 2010; Caswell 2011; De la Puente 2008, 2010 and 2013; Rotman 2009 and 2012; the short articles published in International Journal of Middle East Studies 49/1 (2017); and the contributions to Gordon and Hain 2017. 
references to the slave trade found in historical sources. Thanks to numismatic and archaeological research, for instance, we have now started to understand how the geographies of slave raiding and trading and the formation of mercantile networks related to regional demand. ${ }^{2}$ In addition, papyrological studies have greatly enhanced our understanding of the specifics of, and variety among, Islamic laws concerning slave acquisition and their relationship with legal documentary practices. ${ }^{3}$ Importantly, these and other recent scholarly contributions allow us to better understand the realities that lay behind the reports and anecdotes, often of unclear historicity, on slave-entertainers, concubines and eunuchs held by the urban elite, which figure so prominently in historical and other literature. ${ }^{4}$ Yet many aspects of the various forms of the slave trade in the early Islamic period remain to be explored. These include the question of how slave traders were organised and how they used, maintained and transported their human merchandise, for example, and how closely the mechanisms of slave acquisition and the social economics involved therein conformed with the prescriptions found in legal and advice literature.

Private and business letters from this period, together with contemporary legal documents, open new windows onto the organisation and dynamics of the slave trade. With the exception of a small number of publications, ${ }^{5}$ historians of slavery in the first Islamic centuries have generally not used these documents. ${ }^{6}$ Although it often is impossible to know these documents' exact date and provenance, to identify the individuals they mention, or to fully grasp their unique historical contexts, they nevertheless offer invaluable snapshots of the everyday business of slave traders, the concerns of those wishing to buy a slave, and the activity at slave markets. ${ }^{7}$ In contrast to previous studies that have been based primarily on literary texts, this article offers a socio-historical study of the Abbasid-era slave trade by addressing documentary sources, including five documents that are presented in the appendix. When possible, it combines or contrasts these documents with information gleaned from a wide array of historical, geographical and legal sources. It focuses on different

2 Gaiser 2013 and Jankowiak 2015, 2017.

3 Rāgib 2002-6: volume 2. See also De la Puente 2008 and Vanthieghem 2014a.

4 Van Gelder 2004 analyses literary motifs in stories about slave girls; Gordon 2009 studies the value of two key texts for the social history of slave-entertainers. See also Kilpatrick 1991.

5 Rāgib 1996, 2002-6; Richards 1991; Bruning forthcoming. See also Rāgib 2013, which likewise makes use of much non-literary material.

6 Specialists have called for studying them, e.g. Perry 2017: 135-6 and Gordon 2017: 2.

7 For an assessment of the contribution of papyrology to the history of early Islam, see Sundelin 2004. 
facets of the slave trade: the networks of professional slave merchants, the socio-economics of slave acquisition, and the commercial dynamics at a slave market. The article starts, however, with a discussion on the activities of slavers.

By the third/ninth century, slaves in Egypt were mostly born into slavery or were the captives of slavers who imported them from outside the Realm of Islam. Other forms of enslavement that had been licit in the eyes of legal authorities in the late first/seventh and second/eighth century, such as bonded labour to work off debts, ${ }^{8}$ are not recorded to have found the support of third/ninthcentury and later Egyptian jurists. ${ }^{9}$ The data currently available about slavery in Egypt does not allow us to establish the ratio of slaves-by-birth to imported slaves..$^{10}$ However, documents recording the purchase of slaves and indicating whether the bought slave was born outside the Realm of Islam or a descendant of slave-parents strongly suggest that imported slaves dominated Egypt's third/ ninth- and fourth/tenth-century slave market. ${ }^{11}$ Only two of the sixteen documents of this type that have currently been published record the acquisition of a person born into slavery. ${ }^{12}$ The other documents predominantly record the

8 Schneider 1999: 135-46.

9 For example, 'Abd al-Rahmān b. al-Qāsim (d. 191/8o6; cited in Sahnūn 1905, 13:56), his younger contemporary Ibn 'Abd al-Ḥakam 2011: 314, and the Alexandrian Ibn al-Mawwāz (d. 269/882; cited in Ibn Abī Zayd al-Qayrawānī 1999, 10:8, 10) subscribe to the dictum that "a free man shall be neither sold nor hired because of his debt".

10 We lack information on living conditions, mortality patterns and sex ratio, for example, that is needed to establish such a proportion. See Harper 2011: 69-78.

11 Rāgib 2002-6, 2:30-3 [§§ 75-82]. Cf. Gordon 2017: 34 for the opposite situation among the concubines and slave-entertainers in contemporary Baghdad and Samarra. The Egyptian al-Ṭahāwī (d. 321/933) considered the indication of the slave's origin or kind an optional part of legal documents recording slave purchases (1974, 1:268 = 1972: 106 [Arabic]), whereas the much later al-Usyūțī (d. 849/1445) took the view that the provision of such information was mandatory $(1955,1: 97)$. It is presented as a fixed part in the formularies of the non-Egyptian Ibn al-'Aț̣ār (d. 399/10og; 1983: 33), Ibn Mughīth al-Ṭulayțulī (d. 459/1067; 1994: 166-89), and al-Jazīīi (d. 585/1189; 1998: 189).

12 P.Vente 2 (prob. 261/875) and Vanthieghem 2014a: no. 5 (326/938). See the overview in Vanthieghem 2014a: $184-5$ (up to and including P.Vente 11 ). I took P.Vente 10 and 11 together; they document the purchase of the same group of slaves by the same buyer. I have included P.Cam. inv. Mich.Pap.Q.6, presented as document 5 below. Note that the origin of the slave in P.Vente 1 is unknown. 
importation of Garamantians and Nubians, the latter being a majority among them. ${ }^{13}$ Sources tell that slave merchants sometimes lied about the origin of the slaves they offered for sale. ${ }^{14}$ Nonetheless, that Egypt's slave market relied to a large extent on the activities of slavers and the resale of their merchandise supports the idea that classical Islam's encouragement to manumit slaves and the free status granted to children a slave-woman bore to her master curbed reproduction possibilities within the slave population. ${ }^{15}$

The Nubian origin of many of Egypt's slaves needs further attention. Since the mid-first/seventh century, Egypt and Nubia maintained peace on the basis of the famous baqt, a cessation of hostilities based on a diplomatic gift exchange. ${ }^{16}$ By the mid-second/eighth century, Muslim authorities appear to have considered the baqt a diplomatic agreement. ${ }^{17}$ According to their understanding of this agreement, Egypt would not organise attacks against Nubia if the latter supplied precious goods, among which a few hundred slaves; for its part, Nubia would desist from attacking Egypt in return for Egyptian products, such as textiles and wheat. ${ }^{18}$ In contrast to this Egyptian interpretation of the baqt, Nubian authorities considered it a voluntary gift expressing good

13 Garamantians: P.Vente 5 and 8, Vanthieghem 2014a: nos. 2 and 3. As to the records of purchase referring to Nubians, see Rāgib 2002-6, 2:32 [§ 79]; add Vanthieghem 2014a: no. 4 and document 5 below. Nubian slaves are also referred to in P.Marchands v/1 13 and 14, and possibly implied in P.Cair.Arab.v 295 (= P.Alqab 59). Likewise, many slaves mentioned in documents preserved in the Cairo Genizah are of Nubian origin (Goitein 1967-93, 1:137). Other records of purchase are not explicit as to the origins of the slave. For "black" slaves, see P.Vente 4 and 6; the purchase of a "white" (șfrä) slave is recorded in P.Vente 2 and Vanthieghem 2014a: no. 5 .

14 Rāğib 1993: 733-4; Rāg̈ib 2002-6, 2:31 [§ 78].

15 Lewis 199o: 6-7, 10; Jankowiak 2017: 171.

16 For a useful overview of scholarship on the baqt, see Ruffini 2012: 6-8.

17 Discussions of the baqt ascribed by Muslim historians to early second/eighth-century legal authorities deny the existence of a pact or treaty and maintain that the baqt consisted of "a reciprocal nonaggression assurance" (hudnat amān ba'dunā min ba'd; Ibn 'Abd al-Hakam 1922: 188). From the late Umayyad period on, terminology used in discussions on the baqt changes. According to Ibn 'Abd al-Ḥakam 1922: 189, a second/eighth-century shaykh found a document in the official archives stating "we made a compact and an agreement with you" ('āhadnākum wa-'āqadnākum). The use of this terminology finds confirmation in a diplomatic letter sent by the Egyptian governor Mūsā b. Ka'b in 141/758 to the king of Nubia and Maqurra in which the governor refers to the baqt as "our compact" ('ahd); see Hinds and Sakkout 1981: 218, line 16, and 224, line 63). Pace Levy-Rubin 2011: 9, who argues that the terminology of Mūsā b. Ka'b's mid-second/eighth-century letter also applies to a mid-first/seventh-century context.

18 Halm 1998 provides a useful overview of what the baqt amounted to in different periods. 
diplomatic relations. ${ }^{19}$ Whatever the baqt was in reality, it is likely that no exchange took place when relations were bad. Nubia did not send any slaves to Egypt during what the History of the Patriarchs describes as a fourteen-year war between Egypt and Nubia at the end of the second/eighth century. ${ }^{20}$ It is unlikely that goods were exchanged in years Egyptian governors organised attacks on Nubia. ${ }^{21}$ In addition, Nubia did not supply slaves every year, and when it did so these slaves did not necessarily reach Egypt's markets. The caliph al-Mu'tașim (r. 218-27/833-42), and perhaps also his predecessor al-Mahdī $\left(r .158-69 / 775^{-}\right.$ 85 ), agreed to the delivery of slaves once every three years. ${ }^{22}$ By al-Mas'üdì's (d. 345/956) time, the slaves Nubia sent all became the property of the Egyptian governor and Aswan's Muslim notables. ${ }^{23}$ The baqt, then, should not be seen a sustained source of slaves in Abbasid Egypt. ${ }^{24}$ Importing Nubians by other, more stable, means remained a necessity in order to meet local demand.

If legal prescriptions were followed, Egyptians played little role in the actual enslavement of Nubians. Muslim scholars from the second/eighth century and later understood the baqt to forbid the organisation of raids on Nubian territory, including slave-hunting expeditions. Mālik b. Anas is even reported to have explicitly opposed the buying and selling of Nubians who had been enslaved by their fellows, arguing that the baqt does not allow Muslims to participate even indirectly in the enslavement of Nubians. ${ }^{25}$ According to the Cordoban jurist al-'Utbī (d. 255/869), however, some of Mālik's students claimed that he did not oppose the purchase of Nubians enslaved by the Buja, ${ }^{26}$ tribes living in the Eastern Desert with whom Muslims had made peace on terms very similar to the Egyptian-Nubian baqt. ${ }^{27}$ Similarly, Mālik is also said to have allowed the acquisition of Buja tribesmen and women whom Nubians had caught on raids into Buja territory. ${ }^{28}$ Most Egyptian scholars of the second/eighth and third/ ninth century, however, disagreed with Mālik's legal reasoning and saw no fault in buying Nubian and Buja slaves, irrespective of the circumstances of their

\footnotetext{
19 Spaulding 1995.

$20 \quad$ History of the Patriarchs 1904-15, 4:503 [617].

21 Al-Nuwayrī 1923-97, 30:349 (copied in Ibn al-Furāt 1942: 45).

22 Halm 1998: 83-6.

23 Halm 1998: 87.

24 Perry 2014: 32-3 makes this argument for the Fatimid period. See also Spaulding 1995: 592-3.

25 Saḥnūn 19o5, 10:108; al-Maqrīzī 2002-3, 1:546.

26 Al-'Utbī, al-Mustakhraja, in Ibn Rushd 1984-7, 4:171-2.

27 Ibn 'Abd al-Ḥakam 1922: 189.

28 Al-'Utbī in Ibn Rushd 1984-7, 4:171-2.
} 
enslavement. ${ }^{29}$ Al-Layth b. Sa'd (d. 175/791) allegedly said that Egyptian scholars "are better informed about the land of Nubia than Mālik b. Anas. A pact was made with them, [stipulating] that we neither raid them (naghzūhum) nor defend them from their enemies. The purchase of whomever their king enslaves (istaraqqa) or whomever they raid from among themselves is licit."30

Were Nubia or the Buja to violate their peace agreements with Egypt, these stipulations could be lifted, thereby permitting Egypt to attack Nubian and Buja territory and to acquire male, female and child captives who could be sold as slaves. For instance, Ibn Ḥawqal (writing between $331 / 942$ and 378/988) reports a Buja attack on Unbū (Ombo) in 232/846-7 to which the general 'Abd Allāh b. al-Jahm (or 'Ubayd b. Jahm) responded with a counterattack during which he killed many Buja tribesmen and took captives. ${ }^{31}$ In 240/854-5, when the Buja raided the Nile valley again and had stopped paying their tribute to the Muslim authorities, ${ }^{32}$ the caliph al-Mutawakkil $(r .232-47 / 847-61)$ sent the general Muhammad b. 'Abd Allāh al-Qummī, who "killed and took prisoners and captives" among them. ${ }^{33}$ Similar expeditions against Nubia have also been recorded. Returning to Egypt in 344/956 from a punitive campaign on Nubia after a Nubian attack on Aswan, for example, an Ikhshīdid general brought with him "one-hundred fifty prisoners and a great number of heads". ${ }^{34}$ In contrast to Byzantine prisoners of war, $^{35}$ there are no indications that captives of Nubian or Buja origin were held to ransom for diplomatic reasons. Many of them must have been led to the market or offered for sale to their old communities. ${ }^{36}$

Whereas such campaigns only sporadically fed the market, the activities of professional slavers and slave merchants provided a steady supply of humans. Since Antiquity, these raiders and traders brought slaves to the main markets of the Nile valley, mostly from Egypt's African hinterland. ${ }^{37}$ Like the just-mentioned generals, professional raiders used the (often local) violation of peace agreements as a pretext to hunt for slaves. For example, a tribal chief

29 Ibn 'Abd al-Ḥakam 1922: 188; al-Kindī 1912: 13; al-Balādhurī 1866: 237-8; al-Maqrīzī 2002-3, 1:546.

$30 \quad$ Al-Maqrīzī 2002-3, 1:546. See also Schneider 1999: 52 .

31 Ibn Ḥawqal 1938, 1:52-3.

32 Al-Ṭabarī 1879-19o1, 3/3:1429; al-Maqrīzī 2002-3, 1:533; Ibn Taghrī Birdī 1929-72, 2:295-6.

33 Ibn H̦awqal 1938, 1:54.

34 Al-Maqrīzī 2002-3, 1:537; idem. 1991, 6:137. See al-Nuwayrī 1923-97, 30:349 for other expeditions.

35 Campagnolo-Pothitou 1995; Rotman 2009: 36-47.

36 For the place of ransom in the economy of the slave trade, see Rotman 2012.

37 Harper 2011: 90-1. 
from the Nile delta is said to have organised an attack on the Buja after the latter had started to raid Qift in the early 20os/late 81os. According to Ibn Ḥawqal, "he spent three years in their country harrying through their territory and taking prisoners." ${ }^{38}$ Timothy Power has convincingly argued that the length of these assaults (not less than three years) probably indicates that the chief responded not only to the Buja's raiding, but also to a contemporary increase in the demand for slaves on the Arabian Peninsula. ${ }^{39}$ Other slavers simply disregarded peace agreements. Because of the Egyptian-Nubian baqt, for example, the above-mentioned al-Layth b. Sa'd explicitly disapproved of "the purchase of those (Nubians) whom unjust Muslims have enslaved or stolen", ${ }^{40}$ thus acknowledging that in practice Egyptians did make slave-hunting raids on Nubia. Tellingly, the notary who wrote P.Vente 9, a deed recording the acquisition of a "non-Arabic Nubian slave-servant" in 372/983, explicitly stated that the slave in question was "neither (the product) of pillage nor of theft" (line 4$)^{41}$

Other slavers sought their luck among peoples with whom Muslim authorities had no peace agreement. The History of the Patriarchs, for instance, tells of raids on the coasts of Asia Minor and Europe, during which "Muslims carried off the Byzantines from their lands and brought a great number of them to Egypt (or Fusțāt [Mișr])".42 Similarly, the fourth/tenth-century Hudūd al-álam

38 Ibn Hawqal 1938, 1:52; the translation is Vantini's (1975: 154-5).

39 Power 2012: 137.

40 Al-Maqrīzī 2002-3, 1:546.

41 The sole positive reference to slaving raids on Nubia in the third-fourth/ninth-tenth centuries I could find is the History of the Patriarchs' claim that the Ikhshīdid Kāfūr was "captured in the lands of Nubia" (1948: 128). Sources confirm this impression for the surrounding centuries. According to the History of the Patriarchs (1904-15, 3:145 [399]), Muslims "were in the habit of stealing Nubians and sold them [as slaves] in Egypt [or, Fusțāt (Mișr)]" in the second/eighth century (for the mid-second/eighth-century date of this passage's source, see Den Heijer 1989: 8 and 145-6). In an oft-cited passage of his travelogue, the fifth/eleventh-century Nāșir-i Khusraw (d. 471/1078) wrote of Nubia that "[t]raders go there taking beads, combs, and trinkets and bring back slaves to Egypt, where the slaves are either Nubian or Greek" (1986: 41).

History of the Patriarchs 1948: 110. Here, it is also said that Byzantines raided Egypt as well. An emotional letter dated to the third/ninth century confirms that during a Byzantine raid on the Egyptian coast "both the sailors and those who are no sailors have been taken away. They took everybody whom they could reach"; see Levi della Vida 1944-5: 214-15 = P.Philad.Arab. 75. For evidence from the slightly later Cairo Genizah on Byzantine raids, see Rotman 2009: 51-2. For other references to slaves taken to Egypt from Byzantine territory, see e.g. History of the Patriarchs 1904-15, 4:429 [543] and Bernard the Wise's travelogue in Wright 1848: 24. See also the fourth/tenth-century John Kaminiates 2000: 107 [§ 65], with Christides 1984: 161 . 
claims that Egyptian merchants stole children from among the "Blacks" living south of Nubia and that they castrated the boys before importing them into Egypt. ${ }^{43}$ The slaving activity of a famous merchant named 'Abd Allāh b. 'Abd al-Ḥamīd al-'Umarī (d. 255/868-9) should probably be seen in this light as well. He ruled virtually independently of the Egyptian governor Ahmad b. Tuulūn (in office 254-70/868-84) over the goldmine area of the Wādī al-'Allāqī in the Eastern Desert. Trade in gold and slaves seems to have financed his activities. Under circumstances that remain unclear, ${ }^{44}$ al-'Umarī attacked a region in Nubia that was a two-months' march south of Dongola and took a large number of captives. Many of them ended up in Aswan. According to Ibn Sulaym al-Uswānī (writing in the fourth quarter of the fourth/tenth century), al-'Umarī and his companions "had such a high number of slaves (raqiq ) that most concubines of the inhabitants (of Aswan) were from among the Nubian captives. They (i.e., the concubines) were known as al-hakiyyāt because of their cheapness." 45

Although most Egyptian slavers must have operated outside the Realm of Islam or kidnapped people during punitive campaigns against Nubia or the Buja, they also enslaved their fellow Egyptians. ${ }^{46}$ Itself based on a source probably written in $252 / 865-6,{ }^{47}$ the History of the Patriarchs tells, for example, that during the first decades of the third/ninth century "Arabs" raided the Wādi al-Natrūn and enslaved some of the monks living there, who subsequently were "dispersed throughout the world" ${ }^{8}$ Likewise, in a fourth/tenth-century paper document, a man from Ushmūnayn writes to a $q \bar{a} d \bar{\imath}$ about his daughter,

43 Hudūd al-álam 1937: 165 [§ 6o].

44 Al-Balawī (1939: 65) writes that al-'Umarī observed Egypt's peace agreement with Nubia "until the chief of the Nubians appeared to him"; Ibn Sulaym al-Uswānī (in al-Maqrīzì 1991, 4:405) maintains that al-'Umarī attacked Nubians only after they had killed some of his emissaries.

45 Ibn Sulaym al-Uswānī in al-Maqrīzī 1991, 4:406. The meaning of hakiyyāt is unknown. Perhaps the word relates to the Coptic 2Hкє, "poor".

46 Pace Jeffrey Fynn-Paul's theory that the Abbasid Realm of Islam formed a no-slaving zone; see Fynn-Paul 2009. In addition to persons being born into slavery and the examples given in this paragraph, note that, disregarding Islamic legal theory, Muslims and nonMuslims were also made captive during revolts and civil wars. In a fourth/tenth-century letter sent from Damascus, for example, the author writes that Qarāmița had attacked the city and its surrounding villages and "had killed people and taken captive women and children (sibä'al-nisā' wa-'l-șibyān)"; Sourdel, Sourdel-Thomine and Mouton 2010: 66. For Egyptian examples, see al-Kindī 1912: 19o, History of the Patriarchs 1904-15, 3:162-4 [416-18], 4:527-31 [641-5] and History of the Patriarchs 1943: 57.

47 Den Heijer 1989: 147.

48 History of the Patriarchs 1904-15, 4:438 [552]. 
who has been kidnapped and enslaved (tamallakat bi-'-riqq) by a man from the same town who wishes to sell her. ${ }^{49}$ Perhaps race-based prejudices played a role in the abduction: on the other side of the document, an investigator reports to the $q \bar{a} d \bar{\imath}$ that the girl is black. ${ }^{50}$ Similarly referring to enslavement on Egyptian soil and the vulnerability of dark-skinned people, a story in Kitāb 'ajäib al-Hind, the core of which must date to the fourth/tenth century and was dedicated to the Ikhshīdid governor Kāfür (d. 357/968), ${ }^{51}$ suggests that a black African travelling along the Nile without company (and social protection) was imagined to be a slaver's likely prey. ${ }^{52}$

\section{$3 \quad$ Slave Traders and Their Networks}

Boasting about the cosmopolitan character of Egypt's markets, the fourth/ tenth-century Ibn al-Kindī claimed that merchants from the Near East, Byzantium, Europe, North Africa and the main Mediterranean islands found in Egypt a ready market for their slaves ("both females and males"). ${ }^{53}$ Indeed, as elsewhere in the third/ninth- and fourth/tenth-century Realm of Islam, ${ }^{54}$ Egypt's demand for slaves in these centuries was high and, as we saw above, its slave market depended much on the importation of human merchandise. The Egyptian jurist Așbagh b. al-Faraj (d. 225/839) reportedly even said that "people desire above all imported slaves".55 Other sources confirm that in addition to the above-mentioned Nubians and Garamantians who appear most frequently in the papyrological slave trade record, ${ }^{56}$ merchants also brought slaves

49 P.Heid.Arab. III 28. Abduction and enslavement within Egypt's borders is also mentioned in later documents. See Perry 2014: 23-4 (on an undated letter from the Cairo Genizah) and P.Vind.Arab. III $5^{6}$ (Ushmūnayn; 698-708/1299-1309).

50 P.Heid.Arab. III 28 verso, text b. For the association of dark-skinned peoples with slaves in classical Islam, see Rotter 1967; Lewis 1990: 28-42 and 54-61; Goldenberg 2003: 133-5, 16875; Pétré-Grenouilleau 2004: 26-34. See also Braude 2002, complemented by Franz 2017: 81-3.

$5^{1} \quad$ Ducène 2015 .

$5^{2}$ Buzurg b. Shahriyār al-Rāmihurmuzī 1928: 49-50.

53 Ibn al-Kindī 1971: 71.

54 McCormick 2001: 733-77; Power 2009: §§ 21-9.

55 Al-Bāji 1912-14, 4:191. Așbagh b. al-Faraj's claim may only be relevant to the Egyptian context; cf. note 11 above.

56 See also Ibn Ḥawqal 1938, 1:162 and al-Ișțakhrī 1870: 54 for Egyptian merchants visiting Buja slave traders in the Eastern Desert and Nubian and Buja slave traders selling their slaves on Egyptian markets. Hilāl al-Ṣābi' (d. 448/1056-7) writes that the Abbasid prince 
of Slavic, European or Anatolian, Berber, and Sudanic African origin to Egypt. ${ }^{57}$ The origins of these slaves indicate that Egypt's slave market depended on Mediterranean, trans-Saharan and Nilotic mercantile networks. ${ }^{58}$

Contemporary private and business letters illustrate how merchants operated in the large and complex networks that sustained this trade. Those who specialised in the slave trade, such as the individuals given the epithet nakhkhās ("someone who drives" slaves to the market) in biographical and related literature ${ }^{59}$ could be deeply integrated in such networks. The slave merchants mentioned in the third/ninth-century P.Cair.Arab.v 295, for example, are said to have referred to "our importer (jalab)". ${ }^{60}$ Other merchants sold slaves on an irregular basis, considering them one of many commodities they could trade in. A third/ninth- or early fourth/tenth-century letter from the archive of the Banū Sa'dān, for instance, tells that a trader in perfumes, wood and oil had sold a female slave to a business associate (who subsequently accused him of having sold her without reporting that she was ill). ${ }^{61} \mathrm{~A}$ close look at two business letters sent by a third/ninth-century slave trader named Jafar b. Makhlad, presented in the appendix as documents 1 and 2, shows that although much of the

and de facto ruler in Baghdad al-Muwaffaq (d. 278/891) had Nubian and Zaghāwā slaves bought for him in Egypt to form his corps of mamluks (1958: 16).

57 The sender of $C P R$ XVI 19 (third/ninth century) writes about his acquisition of a Slavic woman in Fusțāt. The sale of another Slavic woman may be referred to in P.Vind.Arab. I 1 (third-fourth/ninth-tenth century). In the mid-fourth/tenth century, one Abū Muhammad al-Ḥasan b. 'Umar b. 'Uthmān commissioned the making of a tombstone commemorating the death of Nașr the Slav, a freedman $($ mawlā) of his grandfather (see Wiet 1942: 198, no. 3998). A fourth/tenth- or early fifth/eleventh-century ledger records the sale of European or Anatolian (rümī) slaves in Fusțāt (Richards 1991). An umm walad called Rayyiq al-Rūmiyya is mentioned in the third/ninth-century P.Ryl.Arab. I $§$ IX $2=$ P.Alqab 94. For a slave of Berber origin, see P.Vente 3. The unknown author of Hudüd al-álam (1937: 165 [§ 6o]) claims that Egyptian merchants imported humans whom they had captured south of Nubia. In addition, two tombstones for female slaves called Sindiyya ('Abd al-Tawab 1977-86, 2:66 [no. 215]; Wiet 1937: 121 [no. 1853]) may indicate that these women were imported from Sind (modern south-eastern Pakistan); but cf. P.Khurasan 30, commentary to line 4 for another interpretation of the name (in an eastern context).

58 This also counts for the importation of Slavs. According to the fourth/tenth-century al-Muqaddasi (1877: 242-3), merchants brought Slavic slaves to Egypt via the Iberian Peninsula and North Africa.

59 See Ibn Yūnus 200o, 2:61 [no. 152] and 110 [no. 279] and al-Sam‘̄ān 1988, 5:470 for traditionists operating in Egypt known as al-nakhkhās.

6o P.Cair.Arab. v 295, especially line 4, with the corrections in Diem 2012: 30-2.

61 Rāgib 1978b: no. 1, lines 9-19. The archive of the Banū Sacdān was found in Edfu; the other documents are published in David-Weill 1931 (documents A and B). 
day-to-day business of slave traders remains undocumented, the organisation of their trade differed little from that of trade in other commodities.

Via these two letters, Jafar b. Makhlad informs his addressees about his commercial activities. Document 1 gives us most details on the enterprise. He and his companions trade in slaves and mules (recto, line 3). Neglecting the mules in the rest of this letter, Jafar informs his addressees about difficulties he and his companions encountered when they tried to sell their many slaves. He writes that they have with them "slave women (jawārī) and female servants (wașäif)" of whom they have been able to sell "neither few nor many" (lines 4-5) because markets are stagnant and the local inhabitants in "bad conditions" (lines 7-8). They have also brought eunuchs to the market of whom they sold some, although "the majority of them remain (with us)" (recto, lines $5^{-6}$ ). Document 2 raises the same problems (lines 6-8) but ends on a happy note. In an afterthought penned in the right margin, Jafar writes that he has been offered 35 dinars for a female slave. He had hoped to sell her for 40 dinars but nonetheless is "very, very happy" (recto, right margin, line 21). Because these prices are higher than the average slave prices in contemporary Egypt, ${ }^{62} \mathrm{Ja}$ far and his companions may well have marketed their slaves outside the province at a place where slaves were in high demand, perhaps in the Hijāz or in Iraq (cf. document 2, recto, lines 6-7).

Social as well as legal arrangements allowed Ja'far b. Makhlad to ply his trade. He requests from the addressees of document 2 (lines 13-14) to take care of his dependents ( $i y \bar{a} l$ ) during his journey. Such arrangements were far from unique to the slave trade and are regularly found in contemporary letters. ${ }^{63}$ Arrangements of this kind were based on trust and must usually have been made before departure, as in the case of the author of a third/ninth-century letter who informed his addressee that he would soon depart for Fusțāt and added "I entrust (my) dependents to your care" (ūsīka bi-'l-'iyāll). ${ }^{64}$ Needless to say, the necessity to make such arrangements varied. The Fustâtt-based sender of P.Vind.Arab. I 12 (fourth/tenth century) asks his addressee to give his children some wheat because he has been unable to return from what was meant to be a short trip to nearby Jīza. In another letter, the third/ninthcentury cloth merchant Ahmad b. 'Abd al-Mu'min beseeches his son to force

\footnotetext{
62 See below at note 114 .

63 Younes 2013: 42-4 discusses such requests in second/eighth-century documents. See $C P R$ XVI 14 (third/ninth or fourth/tenth century) and P.Hamb.Arab. II 6o (first half of the fourth/tenth century) for later examples.

David-Weill 1965: no. 3, recto, line 11.
} 
one Abū al-Hasan to send money to his wife, whom he has left without enough financial means to bridge the length of his business journey. ${ }^{65}$ In Jafar's case, the appointment of care-takers enabled him to make the type of journey that came with his trade.

In addition to such travel arrangements, Jafar b. Makhlad's two letters show that commonly used legal instruments enabled him and his companions to mobilise the capital needed to engage in wholesale trade in slaves. Because together they form a business association, Jafar informs his addressees of the lack of success in his and his companions' trading activities. This is not made explicit in either of the letters but is alluded to in Ja'far's use of the first person plural instead of the singular. For example, he informs them of the well-being of "our mules and slaves" (document 1, recto, line 3) and expresses the hope that God "grant us good reward in what He ordains for the sale of the slaves" (idem., recto, line 10). ${ }^{66}$ Two of his partners are identified as his sons al-Faḍl and Ismāîl. A third partner, one Muhammad b. 'Umar, seems not to have been kin (document 1, verso, line 1). Via his letters, then, Ja far responds to the widely shared expectation to keep his partners informed about their venture as well as about local market conditions. ${ }^{67}$

By and large, late second/eighth-century and later Muslim jurists distinguished between three types of partnership. A small number of references to these partnership types in contemporary papyri show that merchants, at times at least, followed such legal prescriptions. ${ }^{68}$ Two of the jurists' partnership types fit the situation described in Ja'far b. Makhlad's letters. Ja far and his business partners may well have formed an 'inān partnership for a venture in which all partners invested as much capital as they liked and were each other's agents without standing surety for each other. This type of partnership prescribed neither a distribution of profit and loss commensurate to the individual

65 P.Berl.Arab. II $47=$ P.Marchands II 12.

66 Jaffar may have used the plural in reference to himself; see Hopkins 1984: 148 [§ 149.b] for such use of the plural in papyri. The letter's purpose (keeping acquaintances informed about specific trade activities) suggests that this was not the case.

67 Goldberg 2012: chapter 3. See also McCormick 2012: 55-6 and Wichard 1995: 21.

68 P.Marchands I 1, dated 250/864, records the establishment of an 'inān partnership (see below, incl. note 69). Tillier and Vanthieghem 2018: no. 2 (line 25), dated to 19o/8o6, and the third/ninth-century P.Berl.Arab. II 38 (line 9) refer to a qirä ${ }_{71}$ below). In their letters and legal documents, merchants usually referred to their partnerships in vaguer terms. See e.g. $C P R$ XVI 22 (third-fourth/ninth-tenth century), line 9; P.Bodl.Arab. 1 (date unknown), line 19; CPR XXI 30 (between ca. 249/863 and 314/927), line 2; P.Cair.Arab. I 56 (Dhū al-Qa'da 239/April 854), recto, line 5 . 
investments nor an equal distribution of gains and losses among all partners. ${ }^{69}$ Theirs could also have been a partnership based on full equality of the partners with regard to legal capacity, investment, distribution of profit and loss, agency and surety, called a mufāwada partnership..$^{70} \mathrm{~A}$ third (and common) type of partnership, a qirād (also called muqārada or mud̄äraba), does not fit the situation described in the letters. ${ }^{71}$ Such legal instruments allowed merchants such as Jaffar b. Makhlad and his associates to invest large sums of money in expensive but lucrative commodities and enabled them to secure and regulate commercial cooperation.

Slave traders engaged third parties, such as assistants and agents, to help them maintain, transport and market their merchandise. In document 2 (lines 2-6), Ja'far himself expresses his concern about his inability to dispatch someone with money, but his relationship with this person remains unclear. Other papyrus letters illustrate the involvement of others more clearly. A letter tentatively dated to 219/834 tells, for example, that a merchant named Abū Wahb used a well-known type of contract to hire one Ibn Ḥassān for transporting slaves ( $r a q \bar{\imath} q$ ) to the sender of the letter, who probably lived in Alexandria. ${ }^{72}$ A short letter written at an unknown moment in the second half of the third/ ninth or the first half of the fourth/tenth century, presented as document 3 in the appendix, illustrates the involvement of specialised brokers (sing. dalläl, simsār, also nakhkhās) in the slave trade. Brokers were locals who assisted merchants by advertising and/or selling their slaves on their behalf, ${ }^{73}$ as did a crier ( $m u n \bar{a} d \bar{l})$ mentioned in the third/ninth-century P.Cair.Arab. v 295. Document 3 deals with the sale of a female slave (jāriya) entrusted to the letter's addressee. The addressee had given the slave to the sender who, in turn, engaged a broker to sell her (line 4-5). As local specialists, brokers also assisted those who wished to buy a slave, checking the veracity of claims about the origin

69 An 'inān partnership is so called in Hanafĩ law, for which see Nyazee 1999: 99-157 and Udovitch 1970: 119-41. Mālikī jurists would call it a mufāwaḍ partnership; see Nyazee 1999: 191-2.

In this case, Jaffar's sons (two of the three addressees of document 1 ) need to have been of age. Nyazee 1999: 159-75; Udovitch 1970: 40-118.

71 In a qirä d partnership, an investor charges an agent to trade with his capital in return for a share in the profits. In this type of partnership, agents are not partners of the investor before profit emerges. Before an agent profits, the capital remains the sole property of the investor (Nyazee 1999: 253; Udovitch 1970: 190). In document 1, line 10, Jafar b. Makhlad writes about "the slaves He (i.e. God) bestows upon us as a reward", implying his and his associates' ownership over the slaves.

72 Rāgib 2014: 73-4, lines 19-22, with the discussion on 69-72.

73 For the role of brokers in the slave trade, see Rāgib 2002-6, 2:48 [§ 121]. 
and health of a slave and assuring the legality of the transaction in general. ${ }^{74}$ Irrespective of who requested their services, in the third/ninth and fourth/ tenth centuries, buyers usually bore the costs of brokerage, ${ }^{75}$ which often consisted of a fraction of a dinar per slave. ${ }^{76}$

\section{The Socio-Economics of Slave Acquisition}

Slave traders, whether importers or resellers, mostly offered their human merchandise for sale on specialised slave markets. ${ }^{77}$ These markets existed only in Egypt's major cities, such as Fusțāt or Alexandria, ${ }^{78}$ where the amenities for such transactions were available (e.g., advertisers, medical experts, acknowledged witnesses, and notaries). ${ }^{79}$ The slave markets in these cities served large areas. P.Marchands $\mathrm{V} / 16$ and 14, for instance, suggest that in the early third/ninth century, inhabitants of the Fayyūm turned to Fusțât for the acquisition of their slaves. ${ }^{80}$ They, and other Egyptians who lived far away from these markets, depended on agents or their personal networks for the acquisition of slaves. Indeed, papyri regularly attest that commerce in slaves was an area of socio-economic activity that went well beyond professional slave traders and their assistants. The second/eighth- or early third/ninth-century sender of P.JoySorrow $34,{ }^{81}$ for instance, writes on behalf of an unnamed woman,

If you — may God have mercy upon you — see fit that Abū Salama meets someone who buys slaves (raqiq ), you should order him to buy a black $[\ldots]^{82}$ (female) servant (khädim) for eighteen dinars. The gold is with

74 Rāgib 2002-6, 2:48-50 [§§ 122-6].

75 Rāgib 2002-6, 2:50 [§ 127].

76 See document 5 , commentary to line 5 .

77 Slave traders may also have sold their slaves en route to such markets. A travelling slave trader (nakhkhās) is possibly mentioned in P.Marchands v/1 3, lines $5^{-6}$ (with commentary).

78 Fusțāț's slave market will be discussed below. In addition to references implying slave trading in Alexandria mentioned above, see Ibn Abī Zayd al-Qayrawānī 1999, 6:176 (on the authority of Ibn al-Qāsim; also in al-'Utbī's al-Mustakhraja, cited in Ibn Rushd 1984-7, 7:385-6) and especially 8:188 (on the authority of Așbagh b. al-Faraj).

79 See Rāigib 1993 and 2002-6 for the organisation of slave markets.

8o See also P.Cair.Arab. v 295. This letter was stored, and probably also received, in Edfu. The sender bought a slave on behalf of the addressee in another location, possibly Aswan.

81 For the date, see the introduction to document 1 in the appendix.

82 The document has اف]. افد سيه, probably an ethnic reference. 
Hammād. I already wrote him about that. So exert yourself to attain that - may God grant you well-being — for she is in need of a servant.

A number of other documents concern a later stage in slave acquisition via one's personal or professional network. ${ }^{83}$ For example, the sender of a third/ ninth-century letter, who probably acted as the addressee's agent, informs the latter of having accepted a slave's price and of having changed the height of a broker's commission. The sender expresses the hope that the addressee will soon send money to finalise the transaction. ${ }^{84}$ Similarly, the sender of the fifth/ eleventh-century P.Vind.Arab. I 17 explains why he and one Abū Bakr have not bought on the addressee's account a black eunuch (khașī) but rather a female slave, whom he will dispatch together with the letter.

The third/ninth- or early fourth/tenth-century letter presented as document 4 in the appendix illustrates well the socio-economic considerations that might be involved in the acquisition of a slave. This letter's sender and addressee, whose names are lost, belonged to a mercantile network, but their exact relationship remains unknown. That they were acquaintances is visible, for instance, in the sender's request for information on the activity of a certain Kayl, probably an agent, who needed not be identified through a patronymic and was evidently known to both. The sender had sent him to bring a female slave ( $a m a$ ) to one Muhammad (lines 4-7), who also needed no further identification. ${ }^{85}$ Later in the letter, the sender indicates that he had been informed about the addressee's intention to sell a female slave named Wașf ("Praise") and states that he wishes to buy her. He is in need of a slave because his dependents had sold one of his own slaves in Barqa (lines 7-8, 13). The

83 In addition to what follows, see also P.Marchands $\mathrm{v} / 113$ and 14 (dated to the first half of the third/ninth century), informing a merchant in the Fayyüm of the purchase of two Nubian slaves, probably in Fusțāț.

$84 \quad$ P.Cair.Arab. v 295 with Diem 2012: 30-2.

85 The reason why this Kayl accompanied the woman remains unknown. It may indicate that the sender traded in slaves himself, but this is not necessarily the case. The third/ ninth-century writer of P.Cair.Arab. v 361, for example, sent his servant (ghulām) Aḥmad with a donkey driver in order to collect something. The private letter P.World, $177=P . R y l$. Arab. I $\S$ VI 1, dated to the third/ninth or fourth/tenth century, contains an urgent request to dispatch a female slave (järiya); the sender urges the addressee, without stating why, to have one Abū Muhammad accompany her. Fear of flight may well be the reason for the sender of P.World, 175 (second document on the page) = P.Ryl.Arab. I $§$ vI 15 (before midfourth/tenth century) to expressly request to send a slave girl (jāriya) "with an escort". This is the case in the fifth/eleventh-century P.Heid.Arab. III 34, whose sender urges the addressee to guard a slave or servant (ghuläm) "so that he will not run away from us". 
sender writes that this slave had been a mudabbar slave (lines 13-14), i.e. a slave who will gain full freedom after his master's death (if the slave's value does not exceed the bequeathable third of the deceased owner's estate). ${ }^{86}$ If the addressee no longer owned Wașf, the sender would like to purchase another slave in her stead (lines 12-14).

Whereas most letters concerning the slave trade in third/ninth- and fourth/ tenth-century Egypt do not reveal why someone would address his or her social network in order to buy a slave, we can, in fact, reconstruct why the sender of document 4 decided to do so. The sender indicates that he wishes to grant the slave he wants to buy the same prospects of freedom (tadbir) as his old slave had enjoyed (line 14). The sender's reason for granting future freedom to the new slave must be sought in law. Many Muslim jurists in the period under consideration seem to have opposed the sale of a mudabbar slave. ${ }^{87}$ Mālik b. Anas and his followers were very explicit in their opposition to such a sale. They held that the owner of a mudabbar slave "can neither sell him nor remove him from the place where he granted it (i.e. tadbir) to him". 88 If the letter's sender subscribed to this law, he and his dependents may have had strong connections with Barqa. Mālikī scholars further held that creditors cannot force a slave owner to sell his mudabbar slave in order to repay his debt to them. ${ }^{89}$ They only allowed the sale of a mudabbar slave in cases that have no bearing on the situation described in the letter. ${ }^{90}$ Only those who subscribed to al-Shāfi'i's thought or that of Ahmad b. Hanbal saw no fault in selling or buying a mudabbar slave. They argued that tadbir is similar to a testament (wașiyya), which, they maintained, can be changed at will. ${ }^{91}$ By contrast, Mālikì and Ḥanafì scholars distinguished between tadbir and a testament, necessitating that the future freedom of the slave was stated in the presence of witnesses and/or in

86 Schacht 1964: 129 and 169 .

87 See the overviews in al-Ṭahāwī 1995, 3:183-4 [no. 1270] and al-Ṭabarī 1999: 35-41.

88 Mālik b. Anas 1985: 814 [no. 6]. See also Ibn 'Abd al-Ḥakam 2011: 464; al-Bājī 1912-14, 7:45.

89 Mālik b. Anas 1985: 814 [no. 6].

9o Such as the sale of a mudabbar slave as repayment for the deceased owner's debt or the sale of a mudabbar slave to himself. Mālik b. Anas 1985: 814-5 [no. 6]; Ibn 'Abd al-Hakam 2011: 469-70; al-Bājī 1912-14, 7:45-7. See also the Basran Ibn al-Jallāb (d. 378/988) 1987, 2:9-10.

91 Al-Shāfici (2001, 9:307-13) spread two views: (1) that tadbìr can be revoked at will and (2) that tadbir can only be cancelled by removing the slave from the owner's property. In his al-Umm, al-Shāfīi (20o1: esp. 313, followed by al-Muzanī 1994: 421-3) explicitly prefers the first view. Al-Buwayți 2009-10: 1157 maintains that tadbir can only be annulled when the owner removes the slave from his property. For Ḥanbalī Islam, see al-Kawsaj 2004, 8:4441-2 [nos. 3176-7]. 
an official document. ${ }^{92}$ Although adherence to the thought of al-Shāfici, Ibn Hanbal or their students may explain why the sender's dependents sold his slave, ${ }^{93}$ it does not tell us why the sender himself saw the need to indicate the status of this slave to the addressee.

By so doing, the sender expressed his urgent need to correct what he perceived as a transgression of Mālikì or Ḥanafĩ law. Jurists opposing the sale of a mudabbar slave decreed that such a sale must be cancelled. They also maintained that cancelling the sale of a mudabbar slave is impossible when the buyer has removed the slave from his property by reselling him or setting him free, or when the slave has died. ${ }^{94}$ Were this the case, jurists prescribed that the seller use the price he received for his mudabbar slave to grant another slave future freedom. ${ }^{95}$ For example, 'Abd Allāh b. 'Abd al-Ḥakam (d. 214/829) wrote the following about a mudabbar slave in his al-Mukhtașar al-kabir:

When he is sold in ignorance (i.e., the owner does not know of his tadbir) and he then dies in the possession of the buyer, the sale is valid and he (the buyer) cannot claim the restitution of the price upon the seller. Rather, the price of the mudabbar slave should be established (as) if his sale as a mudabbar slave were permitted because of the risks and prospects (of attaining freedom). ${ }^{96}$ The seller is entitled to this price. He should see if there is any surplus in the price (the mudabbar slave was actually sold for) and buy with it a slave to whom he grants tadbir , like the first slave. ${ }^{97}$

Not all contemporary jurists agreed with Ibn 'Abd al-Hakam. The Egyptian Ashhab b. 'Abd al-'Azīz (d. 204/819) and 'Abd Allāh b. Wahb (d. 197/812), for example, allegedly maintained that the buyer should spend the entire price on

92 For witnessing over tadbīr, see Ibn 'Abd al-Ḥakam 2011: 464 and al-Shaybānī 2012, 5:1879o. Two legal documents recording a slave's tadbir have been published: P.Ryl.Arab. I $§$ XV 66.b (third/ninth century) and Grohmann 1935: no. 7 (Nubia, 304/916-17; partially republished as Chrest.Khoury I 22). See al-Shaybānī 2012, 8:168-9 and al-Ṭahāwī 1974: 70410 for models of such documents.

93 Note that there were very few followers of Ibn Hanbal in third/ninth- and fourth/tenthcentury Egypt, including Barqa. See Leiser 1981: 156-9.

94 Ibn 'Abd al-Ḥakam 2011: 470; Saḥnūn 19o5, 8:11-12; al-'Utbī in Ibn Rushd 1984-7, 15:113; Ibn al-Mawwāz in al-Bājī 1912-14, 7:45; al-Ṭahāwī 1995, 3:183-5.

95 In addition to what follows, see also Ibn al-Qāsim in Ibn Rushd 1984-7, 15:192-3 and Saḥnūn 1905, 8:11-12 (see also the fourth/tenth-century al-Barādhi'ī 2002, 2:544).

96 Ar. al-rajä’ Sahnūn 1905, 8:12 has rajä’ al-itq.

97 Ibn 'Abd al-Hakam 2011: 470. 
the future manumission of a new slave, ${ }^{98}$ as the sender of document 4 seems intent to do (see lines 12-13). The North African Sahnūn (d. 240/854), by contrast, reportedly spread two views, one in agreement with Ibn 'Abd al-Hakam and the other saying that the seller should return the surplus to the buyer. ${ }^{99}$ Regardless of these different opinions, the situation described in document 4 is clear. The addressee spread word of his intention to sell the woman named Wașf. Having been informed about this, the sender wished to seize the opportunity to make up for his dependents' transgression of the law in Barqa by granting this slave tadbir after having purchased her.

\section{Commercial Dynamics at Slave Markets}

As noted above, it was at specialised markets that most slaves changed hands. Of Egypt's third/ninth- and fourth/tenth-century slave markets, only Fusțāț's has received attention in historical literature. In contrast to the whereabouts of commerce in slaves in Fusțāt before the mid-third/ninth century, ${ }^{100}$ the location of the city's slave market in the century and a half that followed Ahmmad b. Tūlūn's appointment as governor over Egypt in 254/868 is well known. According to Ibn Duqmāq (d. 809/1407), Aḥmad b. TTūlūn turned a square in one of Fusțâț's most densely populated quarters into a slave market in 255/868-9. ${ }^{101}$ This market, equipped with a bench reserved for the market's superintendents $\left(u m a n \bar{a}^{3}\right),{ }^{102}$ was located just east of the Mosque of 'Amr b. al-Āṣ and was easily accessible: four streets led to this square. ${ }^{103}$ Six years later, Ibn Țūlūn made this market an endowment for the upkeep of his hospital, ${ }^{104}$ probably meaning that merchants could rent shops and/or pens at the market. Despite this slave market's temporary relocation to a compound called al-Dār

\footnotetext{
$98 \quad$ Al-Lakhmī 2011, 9:3932.

99 Al-Lakhmī 2011, 9:3932. See also note 94 above.

100 Ibn 'Abd al-Hakam (1922: 92) writes about a compound in Fusțāț's centre where slaves were sold in the mid-first/seventh century.

101 Ibn Duqmāq 1893, 4:12, 34.

102 Ibn Duqmāq 1893, 4:23.

103 On her map, Denoix 1992 locates the square of Dār al-Anmāț (R9), "which was known as the Slave Market in the past" (Ibn Duqmāq 1893, 4:36), in square E.XV. Denoix locates three of the four streets mentioned by Ibn Duqmāq (1893, 4:12 and 36) as having led to the slave market in Dār al-Anmāț's direct vicinity: Darb al-Macāșir (D48) in square F.XIV and both Zuqāq Banī Jumaḥ (Z2) and Zuqāq Banī Ḥasana (Z26) in E.XIV.

104 Ibn Duqmāq 1893, 4:34; al-Maqrīzī 2002-3, 4:691.
} 
al-Bayḍāa in 354/956-7, ${ }^{105}$ this part of Fusțāt remained associated with the slave trade until the first decades of the fifth/eleventh century. Archaeologists excavated there leaves from a late fourth/tenth- or early fifth/eleventh-century ledger in which a slave trader or broker recorded the transactions of the market's merchants, possibly including those of his own. ${ }^{106}$

A certain Muhammad b. Khālid was among those who bought a slave in Fustạaț. A deed of acquisition, datable to ca. 235-317/850-930 and presented in the appendix as document 5 , records that he purchased a woman named Shu'la from one Ash'ath b. Muhammad with the unspecified help of a broker.107 With the exception of a very few other documents, ${ }^{108}$ deeds of acquisition such as document 5 are our only contemporary non-literary sources for information on commercial dynamics at Abbasid-era slave markets. Although they show us market dynamics from a narrow legal perspective and largely neglect such aspects of commerce as advertisement, inspection and price negotiation, ${ }^{109}$ they are worth studying in detail.

Above all, deeds of acquisition show the need for meticulously documenting the involved parties' informed consent concerning the merchandise and its price. ${ }^{110}$ Like contemporary Egyptian deeds of slave acquisition, ${ }^{111}$ for example, document 5 proceeds, after identifying the buyer and seller, to present a general description of the merchandise under transaction: Shu la was an unspecified slave (jāriya) of Nubian origin. Merchants and buyers differentiated between the origins of enslaved people, to which advice literature on the acquisition of slaves ascribed different qualities, ${ }^{112}$ as well as between various

105 Ibn Duqmāq 1893, 4:34.

106 The ledger is published and discussed in Richards 1991; see also Rāgib 2002-6, 2:49 [§ 123]. For the excavations, see Kubiak and Scanlon 1989: 1-2 and 64.

107 For Fusțât being the document's likely provenance, see the introduction to document 5 in the appendix.

108 E.g. the above-mentioned P.Cair.Arab. v 295 (third/ninth century) and the unpublished Cambridge University Library, inv. Mich.Pap.A.26 (third/ninth or fourth/tenth century). I am preparing the latter for publication.

109 P.Cair.Arab. v 295, lines 3-4, refers to price negotiation. See Rāgib 1993, volume 2 of Rāgiib 2002-6, and Barker 2014: 285-353 for more elaborate discussions of commercial dynamics at slave markets, which include practices for which only literary source material is available.

110 Barker 2014: 307.

111 For an elaborate discussion of the contents of deeds of slave acquisition, see volume 2 of Rāgib 2002-6.

112 Most famously, Ibn Buțlān 1973: 371-8. See also Müller 1980: 64-71, 85-8, 99-101, 104-5, 12442, 184-7. 
types of slave. ${ }^{113}$ They adjusted their price accordingly. Hence, it is very likely that Shula's price, of which only the words "five [and ... dina]rs and half (a dinar) and two carats" (lines 3-4) have been preserved, differed little from that of similar female slaves. Whereas prices of slaves recorded in third/ninth- and fourth/tenth-century papyri vary from 10 dinars to (the rather exceptional) 110 dinars, ${ }^{114}$ single Nubian women are recorded to have been sold for 13, 13 1/4 and 15 dinars. ${ }^{115}$ Most likely then, Muhammad b. Khālid acquired Shula for $151 / 2$ dinars and two carats or for $251 / 2$ dinars and two carats. ${ }^{116}$

Before buying her, Muhammad b. Khālid may have subjected Shula to an inspection in order to determine her physical and psychological health. ${ }^{117}$ Such inspections were deeply humiliating and served not only to verify the price the merchant had set but also to reinforce the unequal power relationship between owner and owned. ${ }^{118}$ Some form of physical inspection is implied in lines 10-11. They record that Ash'ath b. Muhammad had informed Muhammad b. Khālid of the presence of scars near one of Shu'la's ears and on her belly. Some jurists prescribed that merchants not only mention such vices but also place their hands on them, ${ }^{119}$ thereby possibly showing parts of the female body which belonged to the shame zone ('awra) of free women. ${ }^{120}$ Inspection was deemed particularly necessary in case the seller claimed that the slave possessed physical characteristics or skills that directly influenced the price. That the above-mentioned ledger from Fusțât describes a female slave as "deflowered" (thayyiba [sic]) may indicate that the agent of the North African qā

113 Cf. the terminology of document 1, lines 4-5: järiya (unspecified female slave), wasīfa (female servant), khādim (eunuch); also noted in Rāgiib 2002-6, 2:24.

114 Vanthieghem 2014a: 184-6. These prices reveal the exceptional character of exorbitantly high prices mentioned in contemporary literature, such as in a story recorded by al-Tanūkhī (1978, 4:352-3) telling that al-Ḥasan b. Sahl (d. 236/850-1) spent 1000 dinars on a slave girl in Fusțāț.

115 Respectively P.Vente 9 (372/983), Vanthieghem 2014a: no. 4 (326/938), and P.Vente 7 (355/966). Note that in a model document in al-Shāfi'i's al-Umm (2001, 7:484) the exemplary price of a Nubian slave is 20 dinars (while that of a Persian slave is 30 dinars). See also P.Vente 10 (383/994), which records the sale of a Nubian mother, daughter and grandchild for 40 dinars, and P.Vente 11 (384/994), which documents the sale of the same persons a few days later for 49 dinars.

116 Note that this price did not include the fee a broker received for his services. See the commentary to line 5 .

117 Rāgib 1993: 737-53.

118 Barker 2016: 2-3.

119 Rāgib 2002-6, 2:85 [§ 224], with note 887.

120 Jurists considered sight of a free woman's belly unlawful except by her husband, direct kin or other women. See Johansen 1996: 75 . 
who bought her had inspected her to find out. ${ }^{121}$ Likewise, the cooking skills of the female slave-cook (järiya țabbākha) whose sale the ledger also documents may have been tested, ${ }^{122}$ as contemporary advice literature recommended. ${ }^{123}$ But by and large, papyri bear little testimony to such inspections. ${ }^{124}$ Clauses on the seller's and buyer's acquaintance with a slave, prescribed in shurūt literature, cannot be found in third/ninth- and fourth/tenth-century deeds of slave acquisition. ${ }^{125}$ Neither can clauses that indicate that the skills of a slave have been tested. ${ }^{126}$

Much of the remainder of document 5 records that Ash'ath b. Muhammad had guaranteed the absence of vices considered redhibitory. Unlike model documents prescribed by prominent second/eighth- to fourth/tenth-century jurists that use (variants of) a generic clause, ${ }^{127}$ Egyptian deeds of slave acquisition dating from before the 320s/930s present a list of specific redhibitory vices from which the person under transaction is free. ${ }^{128}$ To be sure, these lists were not made after inspection of the slave. ${ }^{129}$ Ash'ath b. Muhammad's statement that Shu'la was "not insane, [not night-blind,] not the object of someone's legal claim, (and that she had) no vices in the genitals" etcetera (lines 7-10) is typical of contemporary deeds of slave acquisition and belongs to the formulaic parts of the document. Vices mentioned in deeds of slave acquisition form a more or less fixed repertoire, ${ }^{130}$ and often the same three (insanity, nightblindness, and being the object of a legal claim) are the first to be mentioned. ${ }^{131}$

121 Richards 1991: 93 (= fragment 1), line 15. Prospective buyers could inspect a woman's virginity themselves (Rāgib 1993: 741), but sixth/twelfth-century and later authors of hisba manuals preferred that this was either done by or in the presence of women; e.g., al-Shayzarī 1946: 84-5 and Ibn Bassām 1968: 149.

122 Richards 1991: 94 (= fragment 2), line 4.

123 E.g. Ibn Buțlān 1973: 386-7. See also Müller 1980: 77-8.

124 See also P.Marchands v/1 13, line 6. The writer of this third/ninth-century letter informs one al-Ḥasan b. 'Abd al-Salām of his purchase of a Nubian woman who was a skilled hairdresser ( jāriya nübiyya māshița). He writes, "I b[ought] her and she cut hair" (i[shtaray] tuhā wa-mashațat). It remains unclear if these words refer to inspection and if so, whether the inspection took place before or after the sale.

125 Rāgib 2002-6, 2:64-5 [§§ 164-6].

126 Al-Ṭaḥāwī 1972: 19o [Arabic].

127 E.g., Abū Ḥanīfa and his disciples in al-Ṭahāwī 1972: 107 [Arabic]; al-Shāfici 2001, 7:476-8; al-Shaybānī 2012, 5:487.

128 See the introduction to document 5 in the appendix.

129 Rāigib 2002-6, 2:68 and 75 [ § 177 and 196].

130 Rāgib 2002-6, 2:75-85 [§§ 196-223].

131 See document 5 , commentary to line 8 . 
Indeed, notaries used models that included such lists. ${ }^{132}$ This does not mean, though, that the guarantees were meaningless. A buyer was given the option to check the slave he had bought for such vices. If he found a redhibitory vice within a legally specified period, which, depending on the type of vice, varied from three days to one year, he had the right to cancel the sale or to reimburse part of the slave's price. ${ }^{133}$ Even though third/ninth-century and later jurists indicate that in practice slave traders often determined which vices were considered redhibitory, ${ }^{134}$ they also write that legal authorities could force them to take an oath to reveal the truth if buyers claimed their guarantees were false. ${ }^{135}$

Muhammad b. Khālid and Ash'ath b. Muhammad considered it important to record this information in writing. In contemporary legal theory, a third/ ninth-century or later legal document first and foremost served as an aidemémoire. After having concluded the sale, the buyer and seller could choose to hire a notary to write a deed of acquisition in order to document the transaction's most relevant details, such as the identities of the buyer, seller and witnesses, a description of what was sold/purchased, and the price paid for it. Such information could be useful in case the transaction needed to be revisited before legal authorities.

Legal theory did not always fully agree with legal practice. ${ }^{136}$ In the third/ ninth century, legal theory and practice concerning the probative value of

132 See Vanthieghem 2014a: no. 2 (late third/ninth century) for an example of such a model document.

133 Rāgib 2002-6, 2:77-82 [§§ 202-17] and 97-100 [§§ 257-69].

134 Baber Johansen (1996: 84-5) rightly points out that Hanafĩ jurists stuck to "the (slave) traders' customs" ('ädat al-tujjār) in their definition of redhibitory vices. Mālikī scholars, however, at times sought to add nuances to these customs. Arguing for a differentiation between a "light" (khafiff) and full expression of vices, Mālik b. Anas reportedly said that in a light form a vice "constitutes a redhibitory vice for the slave traders, but I maintain that a sale is not cancelled on account of it" (Sahnūn 1905, 10:162). Shu'la's scars near her ear and on her belly illustrate the possible differences between legal literature and market practices. The Mālikī Ibn Habīb (d. 238/853) subscribed to the (according to him, common) opinion that scars are a redhibitory vice (cited in Ibn Abī Zayd al-Qayrawānī 1999, 6:250). For Ash'ath b. Muhammad and Muhammad b. Khālid they clearly were not. The latter explicitly acquitted the seller of his liability for them (lines 10-11).

135 E.g. Ibn Wahb 2004: 9-10; Saḥnūn 19o5, 10:161; Ibn al-Qāsim in Ibn Rushd 1984-7, 8:136; al-Shaybānī 2012, 8:343; al-Sarakhsī n.d., 18:133-4; al-Buwayṭi 2009-10: 724, 726.

136 Much has been written since Émile Tyan (1945:5-14) and Joseph Schacht (1964:192-4) first formulated general statements on this preference in Islamic legal theory for oral testimony. See, e.g., Rāigib 1997, Johansen 1997, Müller 2013, and the publications referred to in the following footnotes. 
documents seem to have concurred. ${ }^{137}$ In the early fourth/tenth century, however, the new doctrine of tahammul al-shahāda (a witness's legal obligation to testify) changed notarial practices and granted legal documents value in court. Most notably, it required legal authorities, usually a qāại or a member of his staff, to validate the testimonies of witnesses mentioned in these documents. ${ }^{138}$ This new doctrine left traces in our papyri. For example, confirming the testimony of witnesses to the acquisition of a Nubian slave in 384/994, a functionary named al-Yasa ${ }^{\mathrm{b}} \mathrm{b}$. Ahmad wrote in the upper margin of P.Vente 11 that "that has been validated before me (șaḥha dhälika indī) by testimonies of what is specified in it (i.e., the document)" when he registered the deed. ${ }^{139}$ Official validation did not depend on the presence of the witnesses' names in legal documents. ${ }^{140}$ Some deeds lack witness clauses but bear the mark of having been approved by a legal authority. ${ }^{141}$ At the top of a deed of slave acquisition dated $326 / 938$, for example, a legal authority endorsed the deed by documenting that in his presence "the seller acknowledged to have taken the price, being thirteen dinars and a quarter (of a dinar), and the buyer acknowledged to have taken the female slave in good condition" whereas the deed does not mention any witnesses. ${ }^{142}$

Document 5 originally had witness clauses but they are no longer preserved. They have purposefully been removed so that the document lost legal value. This removal signifies that a series of transactions, from enslavement to sale on a specialised market, to which the Nubian woman named Shula had been subjected, had come to an end.

Arabic papyri from second/eighth- to fourth/tenth-century Egypt, including such deeds recording the acquisition of a slave as the one Muhammad

\footnotetext{
137 Müller 2018: 366-7. See Tillier 2017: 348-54 for legal value ascribed to documents before the second/eighth century.

138 Müller 2018: 368-71. See also Rāgib 2002-6, 2:116-20 [§§ 307-16], especially for the validation of deeds of slave acquisition.

139 See also P.Vente $8(367 / 977)$.

140 Later jurists did not consider witness clauses to be an indispensable part of legal documents; see Rāgib 2002-6, 2:105 [§ 282].

141 Vanthieghem 2014a: no. 4 (326/938) and P.Vente 7 (355/966); possibly also P.Vente 6 (310/922-3) and Vanthieghem 2014c: no. 9 (second half of the third/ninth century). Cf. Sijpesteijn 2014: 85 .

142 Vanthieghem 2014a: no. 4.
} 
b. Khālid and Ash'ath b. Muhammad had composed, usually do not state for what purpose the slaves in question were purchased. When documents show privately-owned slaves at work, ${ }^{143}$ we mostly see them perform extra-domestic tasks. Some, for instance, ran errands and delivered or collected messages or goods for their masters. ${ }^{144}$ Others assisted their masters on business journeys or managed affairs at home while their masters were travelling. ${ }^{145}$ But, by contrast, those who were acquired to do household chores left little trace in our papyri. Likewise, and understandably, explicit references to concubinage appear infrequently in papyri, ${ }^{146}$ although references to $\mathrm{umm}$ walads (female slaves whose child a master had acknowledged as his own) are by no means rare. ${ }^{147}$ The question of why Egyptians bought slaves and how the work assigned to them related to that of free people, however, goes well beyond the aim of this article and demands a separate study. In the present article I have considered Arabic papyri for what they tell about the Abbasid-era slave trade. I have argued that they record many otherwise hardly documented aspects of this trade, such as the character of Egypt's slave market and its dependence on continuous slave-making and specific interregional trade networks, the (common) organisation of professional slave traders, the social economics the acquisition of slaves could involve, and some commercial dynamics at slave markets. Needless to say, however, this article has not at all exhausted the papyrological record on slavery in Abbasid Egypt and much remains to be discovered.

143 For slaves who worked for the administration, see Rāgib 1996.

144 Among many documents, see $C P R$ XVI 25, P.Berl.Arab. II 41 and 62, P.Cair.Arab. VI 388 and 404, P.Giss.Arab. 13, P.Khalili I 17 (all dated to the third/ninth century); P.Cair.Arab. v 361 and P.Vind.Arab. II 17 (third/ninth or fourth/tenth century); Vanthieghem 2016 (341/95253) and P.Cair.Arab. v 300 (fourth/tenth century).

145 P.Marchands III 35 (third/ninth century); Rägib 1978a: no. 7 (third/ninth century); P.Ryl. Arab. I $\S$ VI $18=$ P.World, 18 o (third/ninth or fourth/tenth century). See also P.Marchands II 31 (third/ninth century), a letter addressed "to the female slaves".

146 The only explicit reference to practised concubinage that I know appears in P.Khalili I 18 (not long after 276/889), whose author, a notable from Fusțāt, explains his long bachelordom (and argues for his heterosexuality) by claiming that he "bought one slave-girl after the other, without marriage ever being on my mind" (line 13, with Diem 1994: 58-82). Other references to concubinage come from legal documents concerning a dowry, stating that the wife has the right to sell any concubine her husband takes: Grohmann 1935: no. 8 (second/eighth century) and P.Cair.Arab. I 41 (279/892).

147 In papyri: David-Weill 1965: no. 9 (second/eighth or third/ninth century); P.Ryl.Arab. I § IX $2=$ P.Alqab 94 (third/ninth or fourth/tenth century). Many tombstones of umm walads have been preserved. See 'Abd al-Tawab 1977-86, 1:50 [no. 49] and 136 [no. 135], Hawary and Rached 1939, 1:11 [no. 12] and 3:109 [no. 1026] for third/ninth-century examples. 


\section{Appendix}

\section{Document 1}

\section{Business Letter Concerning a Stagnant Slave Market}
P.CtYBR inv. 2667
$23.5 \times 21 \mathrm{~cm}$
First half of the third/ninth century
Provenance unknown (Egypt)
Plate I and II

Well-preserved light-brown papyrus. The original cutting lines are preserved at the top, left and right sides. The papyrus contains a large number of minor holes which cause little loss of text. Traces of five horizontal folding lines are visible. The distance between the first four folding lines ranges between 3 and $3.5 \mathrm{~cm}$; that between the fourth and the fifth folding line and the bottom of the papyrus is approximately $5.2 \mathrm{~cm}$. The papyrus is partially discoloured, being slightly darker around the last two folding lines. A similar colour change is visible at the bottom of the papyrus. Taking the distance between the last folding line and the bottom of the papyrus into consideration, this suggests that the bottom of the papyrus was torn off at a sixth folding line. Colour change at the top of the papyrus and the position of holes also suggests that the papyrus was folded once in the middle and for a second time in the middle of the folded papyrus. The text is written in black ink perpendicular to the papyrus fibres on the recto, and along the fibres on the verso. Diacritical dots are used only in two words. The script and layout allow for dating the text to the first half of the third/ninth century. ${ }^{148}$ The script resembles closely that of P.JoySorrow 34.

Recto:

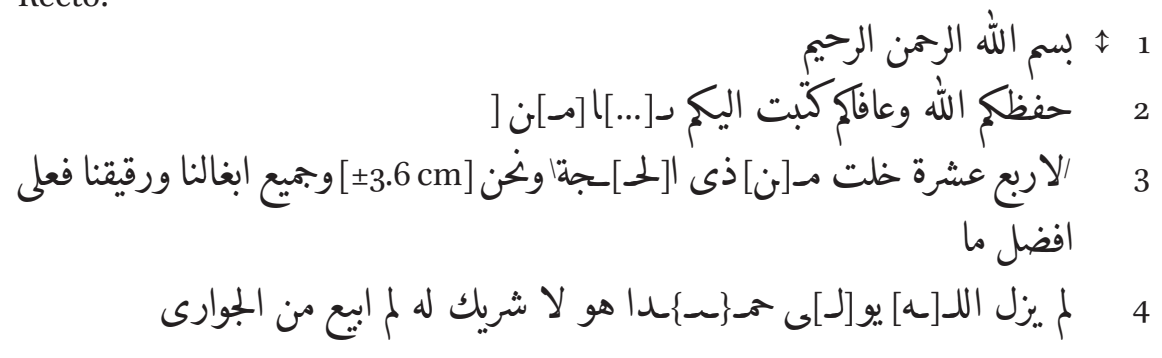

148 Relevant characteristics: a script angle around $67^{\circ}$ and a downward orientation of the overall writing line vis-à-vis the left margin of about $5^{\circ}$; see Grob 2013: esp. 136-37. But compare the dating of document 2. 


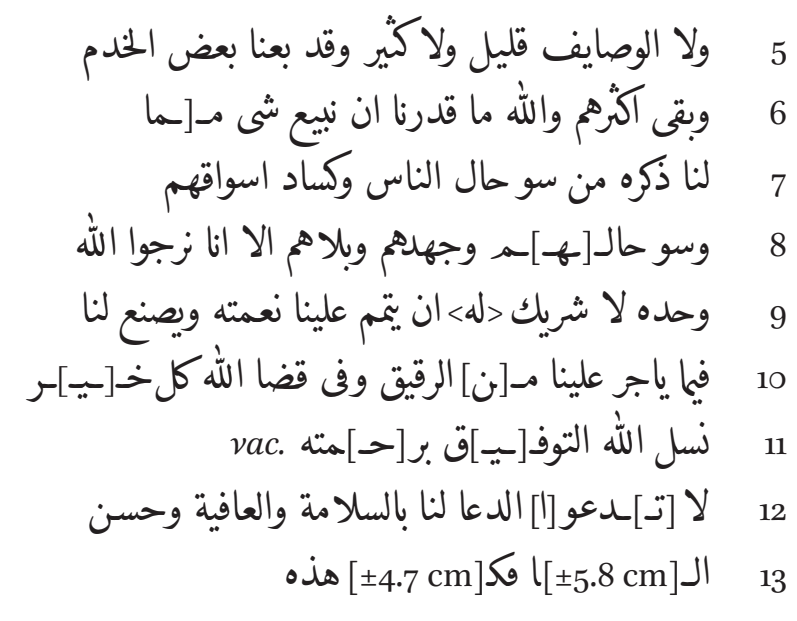

Verso:

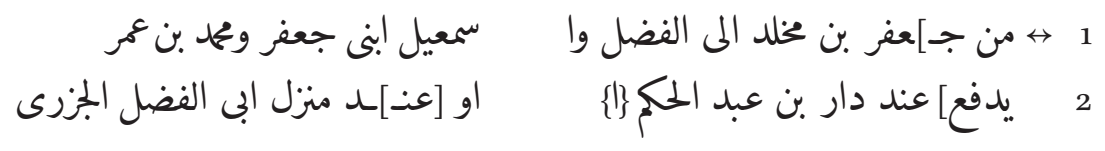

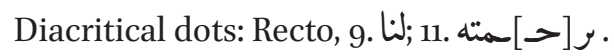

\section{Translation}

Recto:

"In name of God, the Merciful, the Compassionate. May God preserve you and grant you health. I wrote to you [... $]^{\backslash}$ fourteen days into Dhū al-Hijja / while we $[. .$.$] . And (as for) all of our mules and slaves, they are in the best condition,$ for which God, Who has no associate, is continuously praised. I sold neither few nor many of the slave women and female servants. We did sell some of the eunuchs, but the majority of them remain (with us). By God, we have been unable to sell anything of what we have mentioned due to the bad condition of the people (here), the stagnation of their markets, and their miserable state, their distress, and their trials. However, we beseech God alone, < Who has > no partner, that He complete upon us His bounty and grant us good reward in what He ordains for the sale of the slaves-God's decisions contain only good things. We ask God for succ[e]ss through His me[r]cy. Do not [ce]ase [to] pray for our health, well-being, and good $[\ldots]$... [...] this ["

\section{Verso:}

"From Ja]'far b. Makhlad, to al-Faḍl and Ismāîl, the two sons of Ja'far, and Muhammad b. 'Umar. [It should be delivered] at the house of Ibn 'Abd al-Ḥakam or at Abū al-Faḍl al-Jazarī’s dwelling." 


\section{Notes to the Edition}

Recto:

2. After كَت اليك , a religious blessing is expected. ${ }^{149}$

3. The writer started the interlinear remark لاربح عشرة خلت مـ[ن] ذى

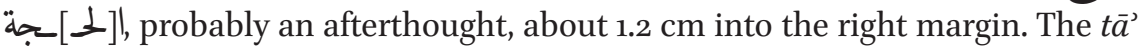
of خلت] is very faded. The nūn of [ن

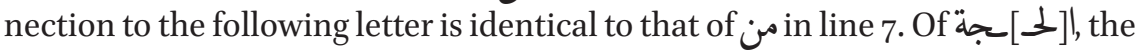
top of the $l \bar{a} m$ is visible just beneath the wāw of gin the line above; some ink belonging to the $h \bar{a}$ ' is visible above the jim. The traces that follow ونغ وكن do not allow for reconstructing common phrases on the sender's well-being that are expected at this point in the letter, ${ }^{150}$ such as (a combination of) wa-nahnu ka-'lladhīyasurrukum or wa-nahnnu 'alā mà tuhibbūna, and would connect well with the second half of the line. Of the first alif in linly traces remain.

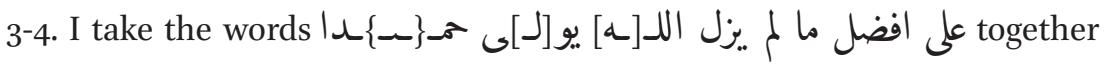
because al-Qalqashandī (d. 821/1418) offers a nearly identical parallel in a copy of a Fatimid letter for the appointment of an amir al-jihäd: "The Commander of the Faithful asks God All-high to make him give and take (an yujriyahu fi-mā yușdiru wa-yūridu) with utmost success in the making and enforcement of his decisions, which continues to be bestowed upon him and to which he is ever accustomed ('alā afḍal mā lam yazal yūlā wa-yu'awwadu min al-tawfiq fira'yihiwa-'azmihi)". ${ }^{151}$ I know of no close parallels in the current papyrological record, but cf. P.Cair.Arab. v 312 (late third/ninth or early fourth/ tenth century), verso line 5 (dawābbuka 'alä afḍal sārrika) and P.Marchands v/1 8(third/ninthcentury), rectoline 7 (shaykhukabi-khayr'alāaf̣̣almātuhibbu). ${ }^{152}$ See Dozy 1927, 2:843 for awlähu hamdan in the sense of "he praised him".

4. In contrast to Classical Arabic grammar, a verb in the indicative or subjunctive rather than the jussive/apocopate follows lam in بيع; cf. Hopkins 1984: 83 [\$ 81.a].

5. In قليل ولا كي", the tanwin alif is absent; cf. Hopkins 1984: 163-64 [§ 167.d].

8. Contrary to Classical Arabic grammar, زوجرا contains an alif; for this phenomenon, see Hopkins 1984: 51 [ $\$ 5$ o.a.i].

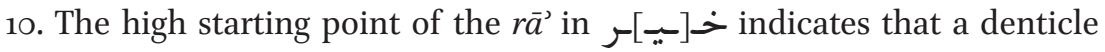
precedes it. See kathïr in line 5 and sharik in line 9 for a similar attachment of the $r \bar{a}$ to a preceding medial denticle.

\footnotetext{
149 Grob 2010: 49.

150 Grob 2010: 48-50.

151 Al-Qalqashandī 1913-16, 10:409.

152 See also CPR XVI 19 (third/ninth century), line 17; and P.Khalili I 17 (third/ninth century), line 3, with Diem 1993: 46.
} 
12. Of Of de dāl and 'ayn are well legible; the wāw is visible but its ink is faint. A direct parallel is found in P.Berl.Arab. I 15 verso (early third/ ninth century), line 9 = P.Marchands III 39, line 5: lā tad'u al-du'à fa-anā ad'ū laka 'alā man ahbabta al-salām. See also Gil 1983, 3: no. 602 (483/109o), line 11:fa-lā tad'uni min al-du' $\bar{a}$, which use of the suffix -ni and the preposition min shows that it is influenced by the common request lā tukhlinnì min al-du' $\bar{a}^{\prime}$, "do not deprive me of (your) prayers", found in documents from the fifth/eleventh century and later. ${ }^{153}$

\section{Verso:}

1. Makhlad, the name of Ja'far's father, can alternatively be read as Mukhallad. Onomastic literature from the fifth/eleventh century and later holds, though, that Makhlad is more common. ${ }^{154}$ The alif of Ismā'ill, Ja'far's second son, is written on the right side of empty space that separates the left and right halves of the address. Ismāill is also one of the addressees of document 2 , see line 9 .

2. يدف is reconstructed on the basis of many parallels; see the discussion in Grob 2010: 77-81. As indicated there, a toponym often follows يدفع in exterior addresses. The lacuna of the present document is not large enough for a toponym. The word $ن$ is written without the prosthetic alif; for this phenomenon in papyri, see Hopkins 1984: 49-5o [ $\$ 49 . b]$. The nisba at the end of the line can be interpreted in various ways: al-Jazarī, al-Kharazī (referring to a group called the Kharaz), and al-Khazarīi. ${ }^{155}$

\section{Document 2}

Business Letter Concerning Various Topics, Including the Price of a Slave
P.CtYBR inv. 2669
$25.2 \times 20.3 \mathrm{~cm}$
Mid-third/ninth century
Provenance unknown (Egypt)
Plates III and IV

Light-brown papyrus in a mediocre state of preservation. The cutting lines are preserved on the left and right sides. The papyrus contains a number of regularly distributed holes (the distances between the holes range between 4.3 and $5 \mathrm{~cm}$ and they are located about $6.3 \mathrm{~cm}$ from the right side), possibly partially on folding lines, which cause loss of text in lines 4, 7, 9 and 13. A larger hole

\footnotetext{
153 For the request using the verb $a k h l a \bar{a}$, see P.Vind.Arab. II 4 (fifth/eleventh century), commentary to lines 7-8 (see also P.Vind.Arab. II 28, line 6 and P.Berl.Arab. II 69, line 3).

154 Ibn Mākūlā 1993-4, 7:223; al-Dhahabī 1962, 2:579; Ibn H̦ajar al-'Asqalānī 1965-7, 4:1268-9.

155 Respectively, al-Sam‘ānī 1988, 2:55, 344, 36o; Ibn al-Athīr 1938-49, 1:225, 354, 369. The nisba al-Khuzazī is irrelevant. Only one Muhammad b. Khuzaz al-Ṭabarānī was known by it (al-Sam‘̄ānī 1988, 2:361 and Ibn al-Athīr 1938-49, 1:370).
} 
damages the second quarter of lines 16 and 17. Like document 1, the papyrus is partially discoloured: the left half of lines 2 and 3 and lines 5 and 6 have a slightly lighter colour than the surrounding papyrus. On the recto, the text is written in black ink perpendicular to the papyrus fibres. The hand is nearly identical to that of document 1 ; see especially the realisation of the final șâd/ dād (for example in al-khalās, line 8 of the present papyrus, and ba'd, line 5 of document 1), the initial and medial kāf (for example in bi-Makka, line 6, and kulluhu, line 7 of this papyrus, and dhikruhu, line 7 of document 1) and the lām-alif ligature (for instance in al-khalās and al-aswāq in line 8 of this papyrus and, respectively, baläihim and wa-lā in lines 8 and 5 of document 1 ). Because, further, both documents are addressed to one Ismā'il (document 1 , verso, line 1; document 2, line 9) and both documents deal with the same topics, it is beyond doubt that the current papyrus' sender is Ja far b. Makhlad, the sender of document 1. On one word diacritical dots are used. The right margin contains an afterthought. Only few and very faint traces of the address on the verso are visible. The script and layout allow for dating the text to the midthird/ninth century. ${ }^{156}$

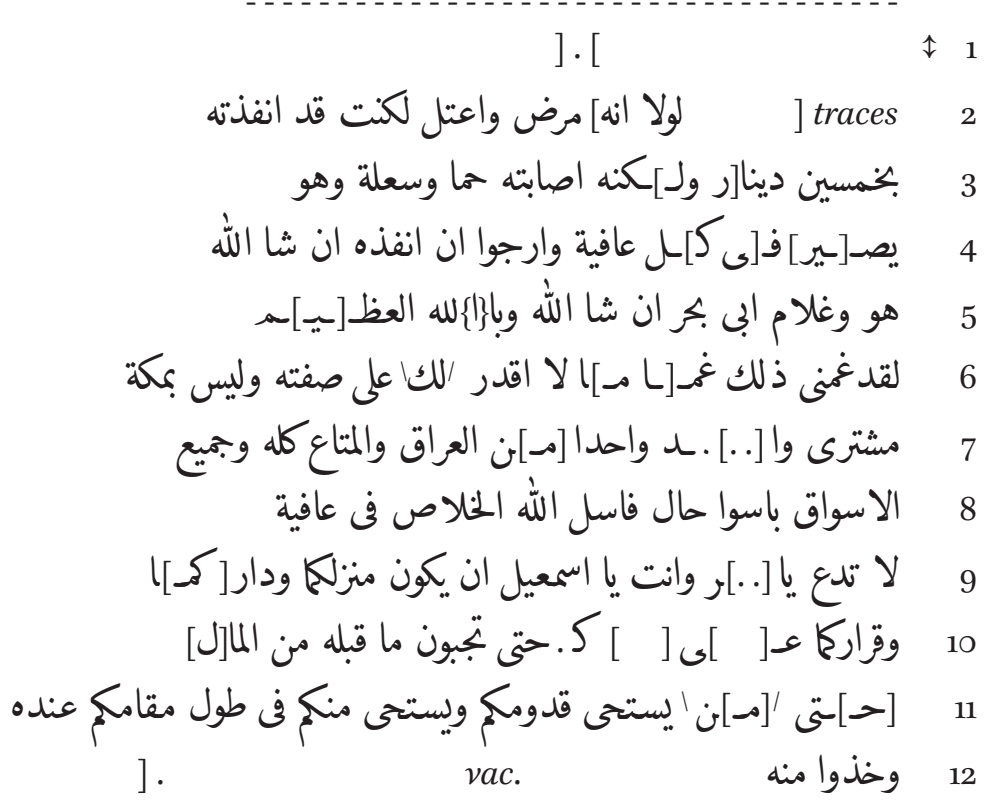

156 Relevant characteristics: the absence of linea dilatans/mashq (Grob 2013: 133-34), a baseline that hangs a little over $6^{\circ}$ (idem.: 134-35), a script angle around $65^{\circ}$ (idem.: 136), and a downward orientation of the overall writing line vis-à-vis the left margin of about $5^{\circ}$ (idem.: 136-37). But compare the dating of document 1. 


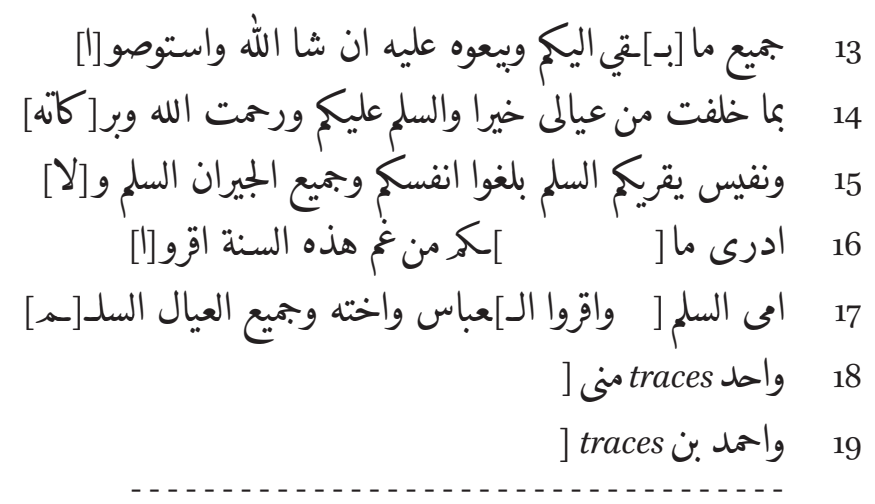

Right margin:

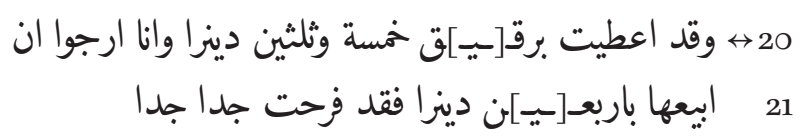

Diacritical dots: 2. ابعدته.

\section{Translation}

Recto:

“... [... Were it not that he] became sick and ill, I would have sent him with fifty dinar[s. Howe]ver, he contracted a fever and a cough. He shall return [to fu]ll health and I hope I can send him, God willing-he and Abū Bahr's servant-God willing. By God Almighty, that distressed me so that I cannot describe it to you. In Mecca, there is no buyer ... one from Iraq. All the goods and all the markets are in the worst condition. So, I ask God for salvation in health. Do not neglect, o [...], and you, o Ismāîl, to make it your house, your dwelling and your residence. [...] until you have collected the money that is with him so that he feels ashamed by your arrival and by yourselves during the full length of your stay with him. Take from him all the remains of your possessions and sell them as a compensation for his debt—God willing. Take good care of those of my dependents whom I left behind. Peace be upon you and God's mercy and bless[ings.] Nafîs sends you greetings. Convey peace to yourselves and to all the neighbours. I [do not] know what [...] you of the distress of this year. Sen[d] greetings to my mother. [... Send al-]'Abbās, his sister and all (my) dependents greet[ings ...] one ... from me [...] and Ahmad b.... ["

Recto, right margin:

"I was offered thirty-five dinars for a (female) slave while I hoped to sell her for forty dinars. I was very, very happy." 


\section{Notes to the Edition}

Recto:

3. For the writing of an alif in lo instead of the alif maqșüra of classical orthography, see Hopkins 1984: 14 [§ 12.a].

4. Faint traces of the letter(s) that follow(s) the șâd in [يصد [ير go below the writing line. For the spelling of ارجوا, see the commentary to document 1, line 8.

5. Onomastic literature records Bahar and Buhur as homographs of Bahr, noting however that Bahr is much more common. ${ }^{157}$

8. The omission of the post-consonantal hamza in فاسل is very common.158

9. Although it is tempting to identify the two persons addressed in this line with Ja'far's sons al-Faḍl and Ismāîl, two of the three addressees of document 1, the onset of a letter before,$[.$.$] and the clearly legible r \bar{a}$ does not allow for such a reconstruction.

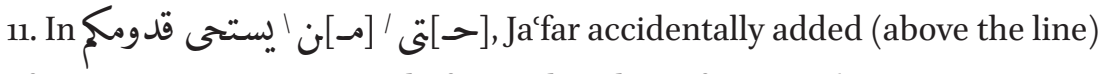
the forgotten preposition min before rather than after yastahì.

15. Instead of the quite common Nafìs, Nufays and Nuqaysh are homographs mentioned in onomastic literature. ${ }^{159}$

Recto, right margin:

20. For the passive of the verb a'tā meaning "to be offered", cf. P.Marchands III 6, line 3: "I displayed them (i.e. cloths) and was then offered ( $\left.f a-u^{\prime} t \bar{a}\right)$ for them one dinar and an eighth (of a dinar), but I want one carat more"; P.Marchands III 40, lines 4-6: "We displayed the cloths but were only offered (nu'tā) a current dinar. We disliked receiving a dinar, desiring (instead) what you consider a good price. If you decide to sell (it) for this (price), respond quickly." See also David-Weill et al. 1978: no. 22, lines 15-17.

\section{Document 3}

A Letter Concerning the Sale of a Woman via Intermediaries
P.Ryl. inv. B III 10 (A) verso
$15.9 \times 28.5 \mathrm{~cm}$
Ca. $235^{-3} 38 / 85^{-}-95^{\circ}$
Provenance unknown (Egypt)
Plate $\mathrm{V}$

Light-brown papyrus. Cutting lines are preserved on all sides except the top, which is frayed without causing loss of text. Because the text stops in the middle of a sentence, the cutting line at the bottom may be secondary and may

\footnotetext{
157 Ibn Mākūlā 1993-4, 1:308-9; al-Dhahabī 1962, 1:52; Ibn Ḥajar al-'Asqalānī 1965-7, 1:67.

$15^{8}$ Hopkins 1984: 29-30 [§ 26].

159 Ibn Mākūlā 1993-4, 7:361-2; al-Dhahabī 1962, 2:647; Ibn Ḥajar al-'Asqalānī 1965-7, 4:1425-6.
} 
have been made when the other side of the papyrus was reused. Starting at $3 \mathrm{~cm}$ from the right side, the papyrus contains three rows of six medium-sized holes. These holes follow each other with six gradually increasing intervals ranging between 3 and $5 \mathrm{~cm}$. These holes, as well as a tear that runs slightly above the middle through line 3 , are caused by folding the papyrus after it was reused for the text on the other side. Characteristic of the script is the realisation of the lamm-alif ligature, which has the shape of a $\mathrm{V}$ (with a sharp point); see wa-salämataka (line 3) and li-abīaha (line 4). The text has few diacritical dots. An oblique stroke is written above the $\sin$ and final $k \bar{a}$. Although the document bears no date, its script and layout allow for dating it to the second half of the third/ninth century or the first half of the fourth/tenth century. ${ }^{160}$

The other side of the papyrus (not edited here) has been reused for a private letter; for a preliminary transcription, see P.Ryl.Arab. I $\S$ vi $9 .{ }^{161}$ This letter's address is written in the left margin on the side edited below and covers the end of lines 2 and 5 . The reused side has no visible traces of an address belonging to the current letter. Palaeography and contents do not establish a link between both sides of the papyrus.

In 1933, D.S. Margoliouth published the editio princeps of this side as P.Ryl. Arab. I § VII 29.

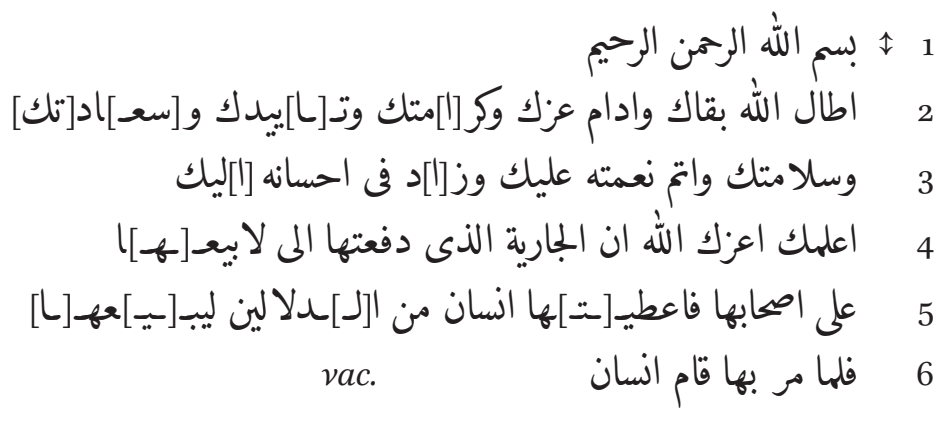

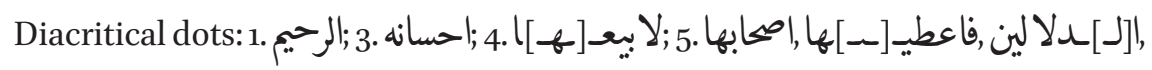

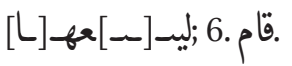

160 The relevant characteristics are: a final alif written without a downward stroke extending below the line (Grob 2013: 131; but see see fa-a'taytuhā in line 5 and fa-lamma, qāma and insān in line 6 for the presence of downward strokes), a relatively small initial 'ayn (idem.: 130), vertical lines tend to slant slightly to the left (about 94 $4^{\circ}$; idem.: 136), a downward orientation of the writing lines when compared to the right cutting line (idem.: 137).

161 Pace the "Index of Papyri" in P.Ryl.Arab. I, which on page 225 incorrectly refers to this side as the recto of P.Ryl. inv. B III 10 (B) and wrongly identifies P.Ryl.Arab. I $§$ VII 4 as the recto of P.Ryl. inv. B III 10 (A). 
Editio princeps: 3. 3. 3 ولما

\section{Translation}

"In name of God, the Merciful, the Compassionate.

May God prolong your life, perpetuate your strength, your honour, your support, your happiness, and your health, and may He fulfil His grace upon you and increase His benevolence to you. I wish to inform you - may God strengthen you - that (regarding) the female slave which you gave me to sell on behalf of her owners, I have given her (to) a man from among the brokers to sell. When he passed by her, a man stood up vac. ["

\section{Notes to the Edition}

2. The editio princeps lacks [وسع][اد[تك]

4. For the gender disagreement between the feminine noun الجارية and the masculine relative pronoun الذى which follows, cf. Hopkins 1984:147-8 [§ 147.b].

5. When it follows the verb $b \bar{a}^{c} a$, the preposition can have the meaning "on the account of", "to the debit of"; e.g. P.Vente 13 (687/1288), line 12: wa-damina li-'l-mushtarì al-darak 'an waladayhi fimà bā'ahu 'alayhimā li-akhīhi, "he (i.e. the seller) guaranteed the buyer indemnity on behalf of his two sons concerning what he had sold on their account to his brother". The reference to the female slave's owners and to brokers makes it unlikely that على has this meaning here and suggests that she was sold "on behalf" of her owners. In a rather crude manner, the writer added the $h \vec{a}$ ' of اصحابها after writing اصحابها The bottom of the $t \bar{a}$ in is visible. For the isolation of the natural subject

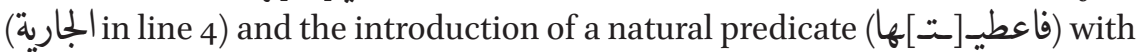
fa-, see Hopkins 1984: 223-25 [ [ 262]. The word السارة, the second direct object of a țaytu, lacks tanwin alif; see also Hopkins 1984: 164 [§ 167.e]. Although the verb $a^{t} t \bar{a}$ can have two direct objects (what is given and its recipient), the preposition $l i$ - before the recipient can only be left out when the recipient is the first direct object. In our case, $l i$ - is erroneously left out.

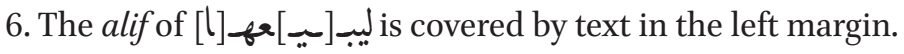

\section{Document 4}

Private Letter Concerning the Purchase of a Slave

$\begin{array}{lll}\text { P.Cam. inv. Mich.Pap.A.113 } & 29.5 \times 23 \mathrm{~cm} & \begin{array}{l}\text { Ca. 183-338/80o-950 } \\ \text { Provenance unknown (Egypt) }\end{array} \\ & \text { Plate VI }\end{array}$

162 Cf. the introduction to document 5, which is also part of the Cambridge University Library's Michaelides Collection. 
Well preserved yellowish papyrus. The original cutting lines are preserved on the left, right and bottom. The top of the papyrus has been cut off, causing the loss of the basmala, initial eulogies ${ }^{163}$ and the beginning of the actual letter, and possibly the address on the back. The upper third of the papyrus (up to line 7) contains small worm holes that cause no severe damage to the text. The rest of the papyrus has virtually no holes. Identical worm holes in the $q \bar{a} f$ of färaqtu (line 6), below the final nūn of ithnān (line 9), below the nün of wa-in (line 12), and below the wāw of yawm (line 19; see also the tiny holes to the left of thamanahā in line 9 and wa-lam in line 12) are located at regular intervals and indicate that the papyrus was folded at least four times with folding lines at a distance of 4.6-5.3 $\mathrm{cm}$ of each other. A strip of papyrus has been broken off at the back, creating holes in line 2. The text is written in a legible hand perpendicular to the papyrus fibres with black ink. The right margin contains an afterthought written along the fibres. Crossed-out writing mistakes in line 4, erased letters or words in lines 11 and 16 (see commentary), a spelling mistake in line 17 , and very cursively written last words in line 19 give the impression that the letter was written rather quickly. The script and layout allow for dating the document to the third/ninth century or the first half of the fourth/ tenth century. ${ }^{164}$ The realisation of the medial $h \bar{a}$ is noteworthy; see for example thamanahā (line 9), bay'ahā (line 11), bitahā (line 12), and ilayhim (line 20). The text contains one diacritical dot in the name Wașf (line 8) and a dot below the 'ayn of 'alä (line 10). The back is empty (cf. above).

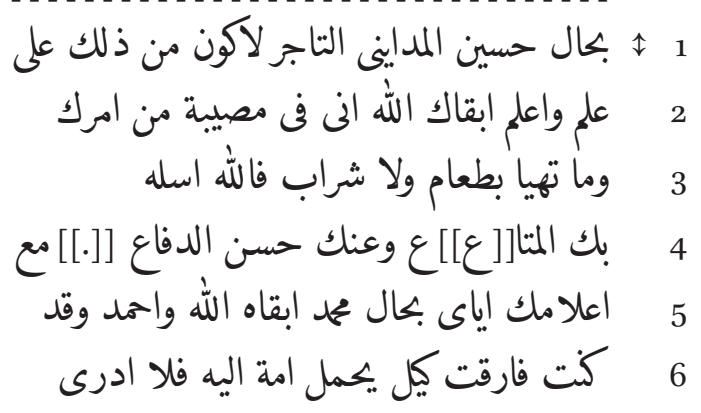

163 According to Grob 2010: 75, the eulogies in line 18 may give a good impression of the eulogies no longer preserved.

164 The relevant characteristics are: a $\sin / \operatorname{sh}$ in written with and without teeth (Grob 2013: 131; compare the realisation of sharāb and husn [in lines 3 and 4] with shäa and al-saläm [in lines 14 and 16]), the absence of linea dilatans (idem.: 133-34), a baseline that hangs at a few degrees (idem.: 134-35), a moderate slanting of the script to the right (idem.: 136), and a downward orientation of the overall writing line of less than $10^{\circ}$ vis-à-vis the left cutting line (idem.: 137). 


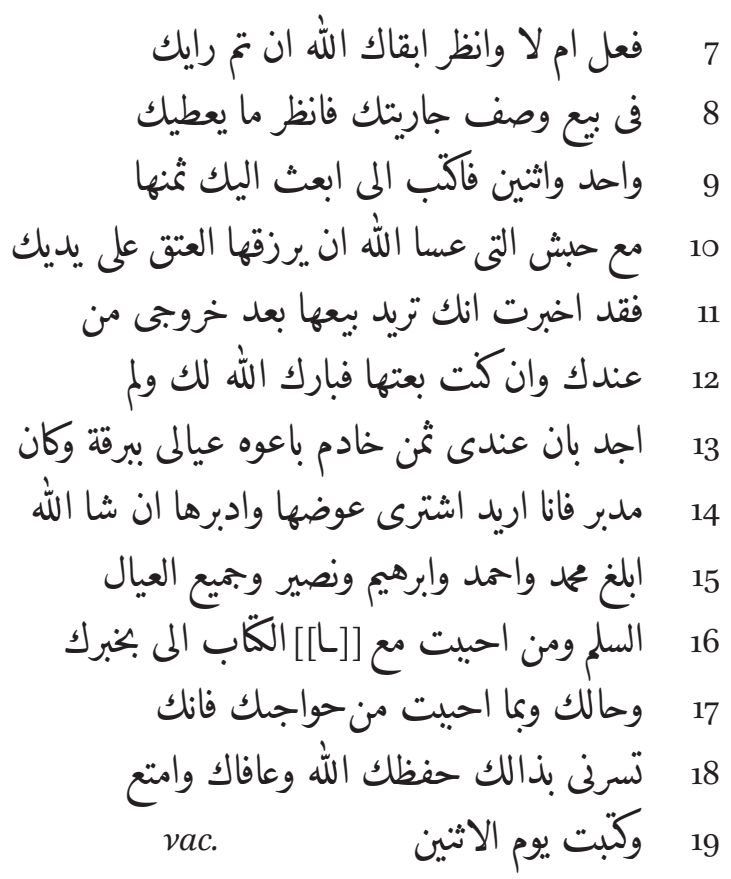

Right margin:

$$
\begin{aligned}
& \text { هـ [يحرز الى واعطى من القرط قليل ولا كثي والقرط غال قليل فاكتب الئم }
\end{aligned}
$$

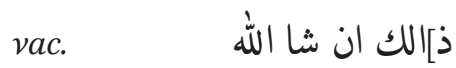

Diacritical dots: 8. على وصف.

\section{Translation}

"] the merchant Husayn al-Madāinī's condition so that I have knowledge of it. Know-may God prolong your life — that I am in a (state of?) calamity because of your affair while he did not prepare food or drink. So, God I ask to grant (us) enjoyment $[[\ldots]]$ through you and defend you well $[[\ldots]]$. Inform me about the condition of Muhammad—may God prolong his life-and Ahmad. For, I departed from Kayl while he was bringing a female slave to him (i.e., Muhammad); and I do not know whether he has done that or not. Look into-may God prolong your life-, when you have reached a decision as to selling Wașf, your female slave, then look into what one or two (possible buyers) would give you and then write to me so that I can send to you her price with Habash, for whom God will perhaps provide emancipation through you. For, I have been informed after I left you that you wished to sell her (i.e., Wașf). 
If you have sold her, God has blessed you. (For,) I did not find with me the price of a servant my dependents sold in Barqa; and he was a mudabbar slave. In that case, ${ }^{165}$ I wish to buy (a slave) in her (i.e., Wașf's) place and grant her tadbir ${ }^{166}$ God willing. Send greetings to Muhammad, Ahmmad, Ibrāhīm, Nuṣayr, all the dependents, and to whom you like. And send a letter to me with your news, condition and what you like (to mention) of your needs. For you will make me happy if you would do that. May God preserve you, grant you health, and grant enjoyment. I have written (this letter) on Monday."

\section{Right margin:}

"] ... to me. He gave neither little nor much of the trefoil. And the trefoil is a bit expensive, so write to them that they should protect it. [... th] at, God willing."

\section{Notes to the Edition}

1. The $w \bar{a} w$ in is partially visible; and because the remnants do not look like final wāws elsewhere in the document (in عوضها , in line 14, باعون 13 line in line 17, and يو in line 19), its reading is uncertain. Yet, the words 'alā ilm in published papyri are nearly always preceded by the preposition li-followed by the verb kāna, which in turn is followed the preposition min. See P.World, 171 (first/seventh century), line 19; P.Berl.Arab. II 53 (second/eighth or third/ninth century), line 7; and P.Cair.Arab. v $301=$ P.Alqab 116 (third/ninth century), line 11; for an example without a prepositional phrase, see David-Weill 1965: no. 2 (third/ninth century), line 10.

2. Due to holes in the papyrus, the reading of is uncertain. A mim can be read with certainty at the beginning, as can be a denticle followed by a $h \bar{a}^{\prime}$ or $t \bar{a}^{3}$ marbūta at the end. The top of this $h \bar{a}^{3} \mid t \bar{a}^{3}$ marbu $t a$ bends to the right, as does the top of the $t \bar{a}^{3}$ marbūta of bi-Barqa in line 13 (but this letter is realised differently in as'aluhu [line 3] and ilayhi [line 6]). The șād is only partially preserved, but the traces are very similar to the dāad in 'iwadahä (line 14) and the $s ̧ \bar{a} d$ in Nuṣayr (line 15). Between the șād and the final denticle, the pen went up at least once more for a small letter, probably another denticle.

3-4. For emphasizing a sentence's predicate by introducing it at the beginning after $f a$-, see Hopkins 1984: 224 [ $\$ 262$.b]. Opening a prayer with the words فالله اسله, or a variant with $w a$-instead of $f a$ - or without such a particle, is known from four other documents: CPR XVI 30, recto line 7; P.Khalili I 18, verso line 19; P.Marchands $\mathrm{v} / 1$ 9, recto line 5; P.Fay.Villages 37, line 6.

165 I.e., when the addressee sold Wașf.

166 I.e., freedom after the owner's death. 
8. The feminine name Wașf (prob. "Praise") is also attested on two tomb stones. One commemorates the death a free woman named Wașf bt. 'Abd Allāh and is dated to the mid-third/ninth century; ${ }^{167}$ the other records the death of a slave (järiya) by this name who died in 330/942 and was buried on the cemetery of Aswan. ${ }^{168}$ Another tombstone, from $261 / 874-5$, attests to a variant of this name: it commemorates the death of an umm walad named Wașfa. ${ }^{169}$

9. The $y \bar{a}$ and second nūn in واثين form a ligature. In this ligature, the $y \bar{a}^{\prime}$ connects with the nün via a short horizontal stroke starting at the high end of the $y \vec{a}$; see حسين in line 1. In fact, such a short horizontal stroke connects final $n \bar{u} n s$ to the preceding letter throughout the document; see من in lines 1, 11 and 16 and the cursively written الاثين in line 19, in which the denticles are reduced to a horizontal line. Hence, that the final nūn in واثنين starts above the word's base line reveals this ligature and that the word should not be read as scriptio defectiva of the grammatically correct wa-'thnān.

10. Medieval onomastic literature record the following homographs of حبش: Jaysh, Hanash and Khuttush. ${ }^{170}$ That Habash etcetera are masculine names, borne by a female slave, is less strange than that it appears to be on first sight. Some female slaves were given masculine names. For instance, Ibn al-Sā'i (d. 674/1276) mentions in his book on female companions of the Abbasid caliphs one Ishāa al-Andalusiyya (d. 270/883), allegedly one of al-Mutawakkil's favourite slaves. ${ }^{171}$ Many other examples are known. ${ }^{172}$

11. Traces of erased letters are visible underneath انك . Only the last letter of the erased word, an alif, can be read with certainty; a denticle may also be visible. Perhaps the writer wrote بew now following on the same line.

13. The lām in عيالى is very short. The ligature lām-yā' in this word is not the same as in 'alā (lines 1 and 10) or ilayya (lines 9 and 16 ).

14. Although a direct object, مدبر lacks tanwin alif. See Hopkins 1984: 163-5 [§ 167.d-f].

15. Literature on anthroponyms record the following homographs of, and alternatives to, Nuṣayr: Bașīr, Nașīr, Naḍīr and Nuḍayr. ${ }^{173}$

16-18. An erased alif is written underneath the 'ayn of 2 . Its lower part is straight and reaches below the line, indicating that this alif was attached to a

\footnotetext{
167 Wiet 1942: 95 [no. 3735].

168 'Abd al-Tawab 1977-86, 3:113 [no. 412].

169 Hawary and Rached 1939, 3:109 [no. 1026].

170 Ibn Mākūlā 1993-4, 2:352-7; al-Dhahabī 1962, 1:255-6; Ibn Ḥajar al-'Asqalānī 1965-7, 1:467-9.

171 Ibn al-Sāī 2015: 6o-3.

172 Dirbas 2019.

173 Al-Dhahabī 1962, 2:642-4; Ibn Ḥajar al-'Asqalānī 1965-7, 4:1418-20; Ibn Mākūlā 1993-4, 1:319-28.
} 
preceding letter; independent alifs in this letter have the tendency to be a bit

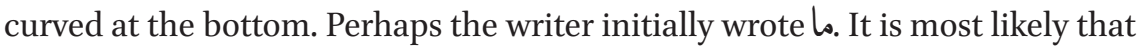

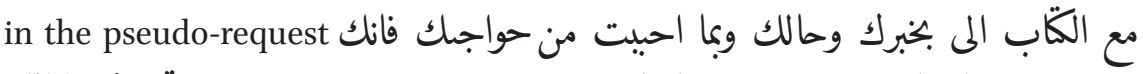

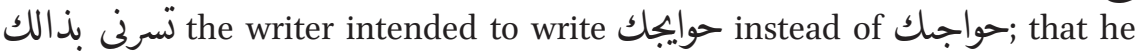
intended to write the singular häjatika ("your need") is less likely. Reference to "news" (khabar) about the addressee and information on the addressee's "condition" (hăl), as in the present document, are common constituents of requests using hawäij. Requests using the singular usually take a different form such as wa-'ktub ilayya bi-mā kānat la-ka min hăja, "and write to me about what you need" (P.Heid.Arab. II 24 [second/eighth century], line 16; see P.Vind.Arab. II 20, line 4 for a fifth/eleventh-century example). ${ }^{174}$ In contrast to in line 18 (see also line 21) is written in scriptio plena; see Hopkins 1984:14 [§ 11].

18. The eulogy وامتع is unfinished and lacks bi-ka, "through you".

19. الاثنين is written very cursively. The thä is not attached to the other denticles, which are reduced to a horizontal stroke.

\section{Document 5}

Deed Recording the Acquisition of a Nubian Woman
P.Cam. inv. Mich.Pap.Q.6
$21 \times 15.5 \mathrm{~cm}$
Ca. $235-317 / 85^{-}-930$
Probably Fusțāt
Plate VII

Light-brown papyrus. The cutting lines are preserved on the left and partially on the top and right. In its current state of preservation, about a quarter of the papyrus is missing in the upper-right corner, causing loss of text in lines 1-5. Identical holes at the bottom (at ca. $1.7 \mathrm{~cm}$ from the left side and ca. $3.5 \mathrm{~cm}$ from the right side) show that the papyrus has been folded in the middle. The folding line formed the left side of the hole in line 9 and ran through holes in the upper margin. The bottom of the papyrus has consciously been torn or cut off when the papyrus was folded. The text is written in a cursive and practised yet legible hand perpendicular to the papyrus fibres with black ink. The final $b \bar{a}^{\prime}\left|t \vec{a}^{\prime}\right| t h \bar{a}^{\prime}$ can be long, as in Ash'ath (lines 2 and 4), or very short, as in 'ayb (line 8), haythu (line 10), and khalat (line 12). The separate $r \bar{a}$ and nün can hardly be distinguished; cf. these letters in dīnār (line 5), al-jāriya (line 6), an (line 7), and kāna (line 10). The final $y \bar{a}$ in $k \bar{a} h \bar{\imath}$ (line 9) is nearly identical with

\footnotetext{
174 For the attestations of both requests and their being pseudo-requests, see P.Berl.Arab. II, $279-84$.
} 
the final $r \bar{a}$ ' in farj (line 8) or hurra (line 9). Two diacritical dots on a single letter are reduced to a very short stroke. The back is empty.

The document's script and layout allow for dating it to the second half of the third/ninth or the first half of the fourth/tenth century. ${ }^{175} \mathrm{~A}$ comparison of the document's legal formulae with that of other third/ninth- and fourth/ tenth-century deeds of slave acquisition suggests a date before the 320s/93os. A clause indicating that the transaction was free of fraud (bay al-muslim min al-muslim $)^{176}$ is absent. This clause appears for the first time in Vanthieghem 2014a: no. 3 (325/937) and can be found in most other deeds of slave acquisition dating from between $326 / 938$ and $372 / 983 .{ }^{177}$ Likewise, in the 320 s/93os, a clause stating that the slave is "without bodily and mental (or moral) defects, and not unlawfully acquired" (lā dā' wa-lā ghä̉ila wa-lä khibtha) replaces an often more elaborate clause, present in the current document and starting with 'alà an laysa lahu after which follow specific vices. ${ }^{178}$

Fusțāt is the document's most likely provenance. Many Arabic papyri in Cambridge University Library's Michaelides Collection, to which the present document belongs, emanate from Egypt's capital. ${ }^{179}$ At least one of the Michaelides papyri is known to have been excavated there. ${ }^{180}$ The text of many others indicate that they were sent to Fusțāt. ${ }^{181}$ Other documents emanate from institutions that were only found in Fusțāt, such as the qă court or the fiscal administration. ${ }^{182}$ Finally, there are also documents that explicitly concern specific locations in Fusțāt, such as a deed for the lease of

175 The relevant characteristics are: a small initial 'ayn (e.g., line 3: tud'ā; lines 7 and 11: 'alā; line 8: $d a^{c} w \bar{a}$ ), an accentuated extension of the final alif below the line (line 5: dīnār; line 7: wa-șāra; line 12: ayyām), and an angle of the individual words' baseline vis-à-vis the general writing line of about $8^{\circ}$. See Grob 2013: esp. 130, 131 and 135 .

176 For this clause, see Rāgiib 2002-6, 2:68 [§ 176].

177 Vanthieghem 2014a: nos. 4 and 5, and P.Vente 7 and 9.

178 The clause $l \bar{a} d \bar{a}^{3}$ wa-là ghăila wa-lä khibtha is first attested in Vanthieghem 2014a: no. 4 (326/938) and can also be found in Vanthieghem 2014a: no. 5 and P.Vente 7, dating from $326 / 938$ and 355/966 respectively. Legal literature claims that the clause was used in the first/seventh and second/eighth centuries outside Egypt, see Rāgib 2002-6, 2:69 [§ 178]. See idem., 2:69 [\$§ 179-81] for various interpretations of the clause.

179 On the collection, see Clackson 1994.

180 Anawati and Jomier 1954: 94.

181 The unpublished Cambridge University Library, inv. Mich.Pap.A.28, Mich.Pap.A.421, Mich.Pap.A.1337, Mich.Pap.A.1357, and the published P.JoySorrow 23 and 38.

182 Tillier 2014: nos. 1 and 2, Tillier and Vanthieghem 2018: nos. 1-3, and the unpublished Cambridge University Library inv. Mich.Pap. B.12/A. See also P.Vente 8, which documents the acquisition of a slave in Fusțāt. 
a room near Saqīfat Jawwād and the city's main street (al-țarì al-ą̧am), ${ }^{183}$ a list of rents of houses located near the same main street and a watchtower that belonged to the tribe of al-Ṣadif, ${ }^{184}$ and a record of payment made for the use of a mill at Sūq Barbar. ${ }^{185}$

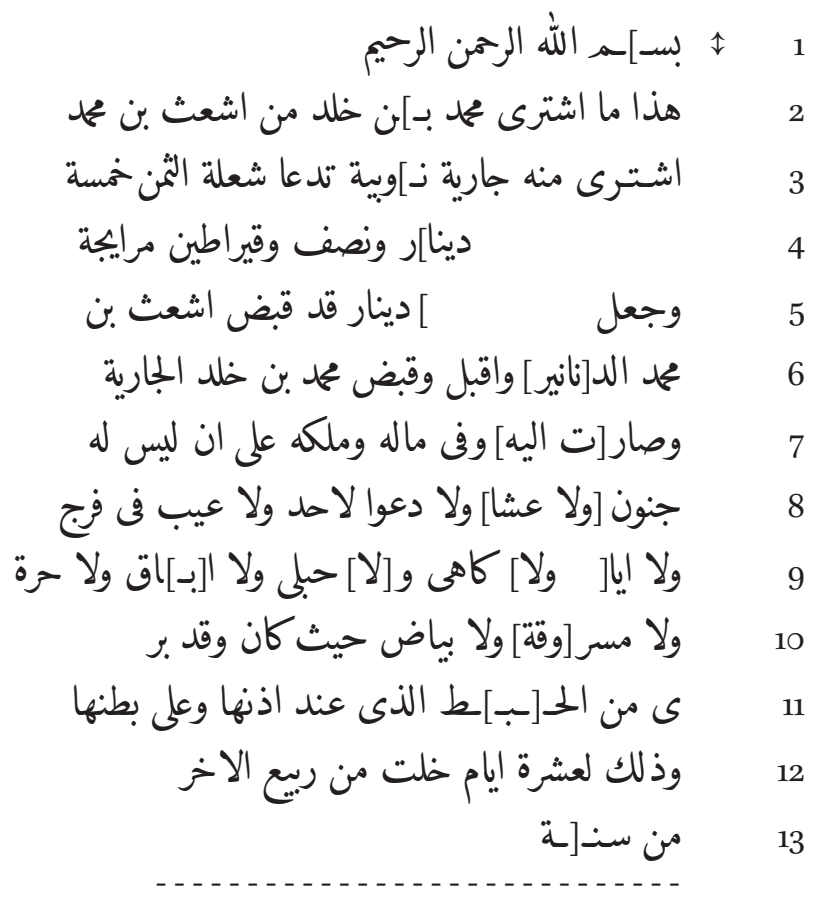

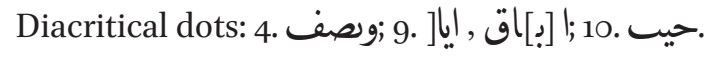

\section{Translation}

"[In na]me of God, the Merciful, the Compassionate. [This is what Muhammad b]. Khālid bought from Ash`ath b. Muhammad. [He bought from him a N] ubian female slave called Shu'la; the price being five [and ... dina]rs and half (a dinar) and two carats in current coin [and a brokerage fee of ...] dinar. Ash'ath b. Muhammad has taken the $\mathrm{d}[$ inars]; Muhammad b. Khālid has received and

183 Cambridge University Library, inv. Mich.Pap.B.327. On Saqīfat Jawwād, see Ibn Yūnus 2000, 1:97 [no. 257] and Ibn Duqmāq 1893, 4:23 and 51.

184 Cambridge University Library, inv. Mich.Pap.CQ.37. For the location of the quarter of al-Ṣadif, east of the Mosque of 'Amr b. al-Āṣ, see Ibn 'Abd al-Ḥakam 1922: esp. 122-3 and Kubiak 1987: 176 .

185 Cambridge University Library, inv. Mich.Pap.B.937, verso. 
taken the female slave. She came into his possession and became part of his property and estate on the condition that it (i.e., the new property) is not insane, [not night-blind,] is not the object of someone's legal claim, has no vices in the genitals, is not ... [...], has no foul breath, is [not] pregnant, has not run away, is not free, not st[olen], and has no whiteness wherever that be. He was acquitted of (the liability for) the sc[a]rs that are near her ear and on her belly. That (being) ten days into Rabíc II of the year ["

\section{Notes to the Edition}

2-3. Deeds of slave acquisition have the usual opening formulae of other sale records. اشترى could equally have been written with an alifinstead of the alif maqșūra; see Hopkins 1984: 15 [§ 12.c] and the commentary to line 8 below. Medieval literature on Arabic onomastics present Ash'ab and Ash'ath as possible interpretations of the slave merchant's ism. The first, however, is uniquely recorded in such literature for the Medinan singer and entertainer Ash'ab b. Jubayr (d. 154/771), which makes this name an unlikely candidate. ${ }^{186}$ Neither Ash'ab nor Ash'ath is attested in published papyri. Al-Ash'ath, a variant of the latter, occurs in CPR III 125 and 126 (= CPR XXII 18), both dated to between $141 / 75^{8}$ and $144 / 761$, and Vanthieghem 2014b (ca. 195/811). Throughout the document, the name Muhammad is written very cursively. Its $h \bar{a}^{3}-m \bar{\imath} m$ ligature is identical to the single $h \bar{a}$ ' in li-ahad and the single jim of junūn, both in line 8. It is unlikely that we should read a single $j \bar{i} m / h \bar{a}^{\prime} \mid k h \bar{a}^{\prime}$ instead of the $h \bar{a}^{\prime}-m \bar{m}$ ligature. The onomastic overviews of Ibn Mākūlā, al-Dhahabī and Ibn Hajar al-'Asqalānī do not record a name with the rasm (such as the modern Majd). Names with this rasm in other papyri should probably be understood as the cursively written name Muhammad. ${ }^{187}$

3. As was usual in early and classical Islamic society, slaves were given Arabic names (if they not already had one) that were mostly not used for free persons. ${ }^{188}$ The name Shula ("Firebrand") is found sporadically as a (masculine)

186 Ibn Mākūlā 1993-94, 1:90-91; Ibn Ḥajar al-'Asqalānī 1965-7, 1:20-21; al-Dhahabī 1962, 1:29. On the historical Ash'ab b. Jubayr and the legends surrounding his life, see Rosenthal 2011.

187 Such as in P.Cair.Arab. II 116, line 4 (the plate allows for reading "Muhammad"), P.Cair. Arab. II 137, line 5 and P.Prag.Arab. 26 verso, line 15.

188 For slave names, see Dirbas 2019 and Rāgib 2013: especially §§ 1-14 of the online edition. Slaves not necessarily lost their original names; see P.Cair.Arab. I 37 (prov. unknown), a record of emancipation ('itq) dated 393/1003, documenting the original name of a emancipated Coptic woman. See also P.Cair.Arab. IV 223 (second/eighth or third/ninth century), line 8; P.Cair.Arab. IV 249 (second/eighth or third/ninth century), line 9; and P.Giss.Arab. 5 . 
name. ${ }^{189}$ But Shu'la is also attested as a nickname and as a horse's name. ${ }^{190}$ The use of the homographic names Sila and Shala, found in pre-Islamic Arabian inscriptions, ${ }^{191}$ is not attested after the coming of Islam.

3-4. I argued above that Shula was most likely sold for $151 / 2$ dinars and two carats or for 25 1/2 dinars and two carats. According to classical Arabic grammar, these numbers take the numbered nouns in the accusative singular. For the common practice to present these nouns in the nominative, see Hopkins 1984: 165-66 [§ 167.h]. The reading of مرايبجة is based on the specification murawwaj, "in current coin", that follows prices in P.Philad.Arab. 14, line 4, and ${ }_{15}$, line 5 (both from Nawāya in the district of al-Ushmūn; both from $300 /$ 912-13), P.Prag.Arab. 15, line 4 (Fayyūm; 302/914-15), and Karabacek 1887: 162, no. 2 (Fayyūm or Ihnās; 344/953).

5. The word دينار after the lacuna indicates that what precedes (in the lacuna) belongs to a clause indicating the money the buyer had paid. In addition to the slave's price, there usually was an additional brokerage fee (jucl) for someone via whom the slave was bought or sold. ${ }^{192}$ In documents recording the purchase of slaves, as well as in those recording the acquisition of animals, a brokerage fee is usually mentioned after the price of the slave or animal, ${ }^{193}$ as is the case here. Whereas most documents do not specify the size of the fee, two documents recording the purchase of a donkey in the second half of the third/ninth century state that the fee amounted to a sixth of a dinar: wa-jul suds (dinār). ${ }^{194}$ The sender of the third/ninth-century P.Cair. Arab. v 295 writes that a crier (munād $\bar{\imath}$ ) advertising a slave was entitled to half a dinar but received only a third. In the present document, a fraction probably preceded dinār.

8. The reconstruction [ولا عشا] is based on the frequently found fixed succession of the defects insanity (junūn), night-blindness ('ashā), and being the object of a legal claim (du'wān fíhi) in contemporary slave-sales, such as P.Vente

189 For a Damascene governor called Shu'la b. Badr al-Ikhshīdī (d. 345/956), see Ibn 'Asākir 1995-2000, 73:174 [no. 9971]; for a companion of the Abbasid caliph al-Mu'tadid $(r$. 279-89/892-9o2) named Shu'la b. Shihāb al-Yashkurī, see al-Mas'ūdī 1966-79, 5:145-7 [§§ 3271-6] and Ibn al-Jawzī 1995, 12:399. For a later example, see the seventh/thirteenthcentury Ibn al-Ṣābūnī 1957: 220.

190 For the nickname, see al-Ṣafadī 200o, 16:93. According to the third/ninth-century Ibn al-Árābī 1985: 81, Shu'la was the name of a horse owned by a certain Qays b. Sibāć.

191 Harding 1971: 320 [s.v. "S'LT"]; Ryckmans 1934, 1:211.

192 Rāgib 2002-6, 2:48-53 [§§ 121-33].

193 The slave-sales P.Vente 2 and 5 and the animal-sales P.Vente $16,18-23$ and Vanthieghem 2014c: nos. 3, 4, and 6 add to the price of the slave or animal wa-'-jul, "plus the brokerage fee". P.Vente 7 (355/966), 8 (367/977) and 24 (401/1011), P.GenizaCambr. 56 (483/109o) and the document edited in Frenkel 2017 (537/1142) state that the price includes a brokerage fee.

194 Vanthieghem 2014c: no. 1 (263/877) and 2 (26o/874 or 266/879-8o). 
2, 5, and 6, and Vanthieghem 2014a: no. 1. ${ }^{195}$ The right side of the wāw in ${ }^{\text {g }}$ ] is visible, as is a small trace of the top of the alif in [عشا. Instead of lä du'wān fini, a regular feature in the formulae of records of the purchase of slaves, ${ }^{196}$ the scribe wrote لا دعوا لاحد. Parallels can be found in P.Khurasan 25 (145/762), line 4 and 28 (149/766), lines 11-12: wa-laysa lì 'alayka sabül wa-lā da'wā qalìl wa-lä kathìr; Grohmann 1948: no. 4 (227/842), lines 7-9: lam yabqā li-Ibrāhìm b. Juwayn qibal Hāsh [im b. Faraj lā qalìl wa-lā kathìr wa-]lā da'wā wa-là țaliba; see also Frantz-Murphy 1994: no. 5 (early fourth/tenth century), line 19. For the presence of an alif instead of the alif maqșūra desired by classical orthography, see the commentary to lines 2-3 above.

9. Traces of the lām in [لآ] are visible.

10. Traces of the $q \bar{a} f$ of $[$ are visible. For the shape of the $t h \bar{a}$ in see the $b \bar{a}$ ' in 'ayb in line 8 and the $t \bar{a}$ ' in khalat in line 12. The words ولاُ legal literature are leucoma (bayāẹ al-'ayn) and grey hair (bayā For another attestation of ولا بياض حيث كان, see Vanthieghem 2014a: no. 6, line 6 (lege thus).

11. The reading of الحـبــ is not entirely certain. The first three letters are well legible. The last letter is not fully preserved, but looks very similar to the $t \bar{a}$ ' in wa-qirătayn (line 4) and bațiha (line 11). The only meaningful word I could find that fits the context as well as those letters that are visible is habat, "scars". 199 The initial $b \bar{a}^{\prime}$ and medial $t \bar{a}^{\prime}$ in بط بre (unintentionally) unconnected. The reason for this should be sought in the scribe's realisation of the $t \bar{a}$. Like his $k \bar{a} f_{\mathrm{s}}$ (see kāhi and kāna in lines 9 and 10), the scribe started the ță at the high end of its horizontal stroke, making it necessary to take his pen off the papyrus. Accidentally, he failed to connect the $t \vec{a}^{3}$ with the preceding $b \vec{a}$.

\section{Acknowledgments}

I would like to thank Wadād al-Qāḍī, Peter Webb and Khaled Younes for commenting on various parts of this article. I am especially grateful to Matthew Gordon for critically reviewing a full draft of the text. Any remaining mistakes are my own.

\footnotetext{
195 See also P.Vente 1 and 3 , in which 'ashā follows junūn.

196 See P.Vente 1, 2, 3, 5, and 6 (dates range between $257 / 871$ and 310/922-23), Vanthieghem 2014a: nos. 1 (272/885) and 2 (late third/ninth century).

197 "Whiteness" is also used unspecifically in al-Bājī 1912-14, 4:188 (line 21) and Ibn Rushd $1984-7,8: 294-5$.

198 Rāgìb 2002-6, 2:70 [ $§ 182]$ and 2:88 [§ 235].

199 Lane 1863-93, 2:502. See also note 134 above.
} 


\section{Bibliography}

\section{Primary Sources}

\section{Papyrological and Epigraphical Publications}

Papyrological abbreviations are those of "The Checklist of Arabic Documents", available at http://www.naher-osten.lmu.de/isapchecklist.

'Abd al-Tawab, 'Abd al-Raḥmān M. 1977-86. Stèles islamiques de la nécropole d'Assouan, rev. and ann. Solange Ory. 3 vols., Cairo: IfAO.

Anawati, George, and Jacques Jomier. 1954. Un papyrus chrétien en arabe (Égypte, $\mathrm{IX}^{\mathrm{e}}$ siècle ap. J.-C.). Annales islamologiques 2: 91-102.

David-Weill, Jean. 1931. Papyrus arabes d'Edfou. Bulletin de l'Institut d'Archéologie Orientale 30: 33-44.

David-Weill, Jean. 1965. Papyrus arabes du Louvre, I. Journal of the Economic and Social History of the Orient 8/3: 277-311.

David-Weill, Jean et al. 1978. Papyrus arabes du Louvre, III.Journal of the Economic and Social History of the Orient 21/2:146-64.

Diem, Werner. 1994. Philologisches zu den Khalili-Papyri, II. Wiener Zeitschrift für die Kunde des Morgenlandes 84: 59-82.

Frantz-Murphy, Gladys. 1994. Papyrus Agricultural Contracts in the Oriental Institute Museum from Third/Ninth Century Egypt. In Itinéraires d'Orient: Hommages à Claude Cahen, ed. Raoul Curiel and Rika Gyselen. Bures-sur-Yvette: Groupe pour l'Étude de la Civilisation du Moyen-Orient: 119-31.

Frenkel, Miriam. 2017. The Slave Trade in the Geniza Society. In Slavery and the Slave Trade in the Eastern Mediterranean (c. 1000-1500 CE), ed. Reuven Amitai and Christoph Cluse. Turnhout: Brepols: 143-61.

Gil, Moshe. 1983. Palestine during the First Muslim Period (634-1099) [in Hebrew]. 3 vols., Tel Aviv: Tel Aviv University and Ministry of Defense.

Grohmann, Adolf. 1935. Arabische Papyri aus den Staatlichen Museen zu Berlin. Der Islam 22: 1-68.

Grohmann, Adolf. 1948. Neue Beiträge zur arabischen Papyrologie: Einige Bemerkungen zu D.S. Margoliouth, Catalogue of Arabic Papyri in the John Rylands Library, Manchester. Anzeiger der phil.-hist. Klasse der Österreichischenen Akademie der Wissenschaften 85: 228-343.

Hawary, Hassan and Hussein Rached. 1939. Catalogue général du Musée Arabe du Caire: Stèles funéraires, vol. 3. Cairo: IFAO.

Karabacek, Josef. 1887. Das arabische Papier. In Mitteilungen aus der Sammlung der Papyrus Erzherzog Rainer, vols. 2-3. Vienna:Verlag der K.K. Hof- und Staatsdruckerei: 87-178. 
Levi della Vida, Giorgio. 1944-5. "A Papyrus Reference to the Damietta Raid of 853 A.D.” Byzantion 17: 212-21.

Rāgiib, Yūsuf. 1978a. Quatre papyrus arabes d'Edfou. Annales islamologiques 14: 1-14.

Rāgiib, Yūsuf. 1978b. Lettres arabes (I). Annales islamologiques 14: 15-35.

Rāgib, Yūsuf. 2014. Lettre d'un marchand d'Alexandrie de la collection Golenischeff à Moscou. Annales islamologiques 48/2: 61-80.

Richards, Donald S. 1991. Fragments of a Slave Dealer's Day-Book from Fusțāṭ. In Documents de l'Islam médiéval: Nouvelles perspectives de recherche. Actes de la table ronde organisée par le Centre National de la Recherche Scientifique (Paris, 3-5 mars 1988), ed. Yūsuf Rāigib. Cairo: IfAO: 89-96.

Sourdel, Dominique, Janine Sourdel-Thomine and Jean-Michel Mouton. 2010. Une attaque de Damas par les Qarmates au $\mathrm{X}^{\mathrm{e}}$ siècle d'apres la lettre d'un marchand. Archiv für Papyrusforschung 56/1: 64-76.

Tillier, Mathieu. 2014. Deux papyrus judiciaires de Fusțāț (II $/$ /VIII e siècle). Chronique d'Égypte 89: 412-45.

Tillier, Mathieu, and Naïm Vanthieghem. 2018. Un registre carcéral de la Fusțāt Abbasside. Islamic Law and Society 25/4: 319-58.

Vanthieghem, Naïm. 2014a. Quelques contrats de vente d'esclaves de la collection Aziz Atiyya. Journal of Juristic Papyrology 44: 163-187.

Vanthieghem, Naïm. 2014b. Un exercice épistolaire arabe adressé au gouverneur Ğābir ibn al-'Ašcat. Archiv für Papyrusforschung 6o/2: 402-5.

Vanthieghem, Naïm. 2014c. Les archives d'un maquignon d'Égypte médiévale? Analecta papyrologica 26: 289-311.

Vanthieghem, Naïm. 2016. Une contribution pour la table d'un prince ikhchidide: Édition de P. Utah inv. 1383. Chronique d'Égypte 91: 433-36.

Wiet, Gaston. 1937. Catalogue général du Musée Arabe du Caire: Stèles funéraires, vol. 5. Cairo: Imprimerie de la Bibliothèque Égyptienne.

Wiet, Gaston. 1942. Catalogue général du Musée Arabe du Caire: Stèles funéraires, vol. 10. Cairo: Imprimerie de la Bibliothèque Égyptienne.

\section{Pre-Modern Literature}

Al-Bājī, Sulaymān b. Khalaf. [1331-2/] 1912-14. Kitāb al-muntaqā. 7 vols., Cairo: Mațba'at al-Sac̄àda.

Al-Balādhurī, Aḥmad b. Yaḥyā. 1866. Futūḥ al-buldān, ed. Michael J. de Goeje. Leiden: E.J. Brill.

Al-Balawī, 'Abd Allāh b. Muhammad. [1358/] 1939. Sìrat Aḥmad b. Ṭūlūn, ed. Muhammad Kurd 'Alī. Repr. Cairo: Maktabat al-Thaqāfa al-Dīniyya [Damascus: Mațba'at al-Taraqqī] . 
Al-Barādhi'ī, Khalaf b. Muḥammad. [1426/] 2002. Al-Tahdhībfìikhtișāral-Mudawwana, ed. Muḥammad al-Amīn walad Sālim b. al-Shaykh. 4 vols., Dubai: Dār al-Buhūth li-'l-Dirāsāt al-Islāmiyya wa-Ihyyā’ al-Turāth.

Al-Buwayțī, Yūsuf b. Yaḥyā. [1430-1/] 2009-10. Mukhtașar al-Buwayțī, ed. Ayman b. Nāṣir al-Salāyimī. MA thesis: al-Jāmi‘a al-Islāmiyya bi-'l-Madīna.

Buzurg b. Shahriyār al-Rāmihurmuzī (ascr.). 1928. Kitāb 'ajāỉb al-Hind, tr. Peter Quennell. London: George Routledge \& Sons.

Al-Dhahabī, Muḥammad b. Aḥmad. 1962. Al-Mushtabih fí al-rijāl, ed. 'Alī M. al-Bajāwī. 2 vols., Cairo: Dār al-Kutub al-'Arabiyya.

Hilāl al-Ṣābi'. 1958. Al-Wuzarā’ or Tuhfat al-umarā’ fì ta'rīkh al-wuzarā', ed. 'Abd al-Sattār A. Farrāj. Cairo: Maktabat al-A'yān.

History of the Patriarchs. 1904-15. Ed. and tr. Basil T.A. Evetts. 4 vols., in Patrologia Orientalis $1 / 2,1 / 4,5 / 1,10 / 5$.

History of the Patriarchs. 1943. = History of the Patriarchs of the Egyptian Church, Known as the History of the Holy Church, tr. Yassā 'Abd al-Masīh and Oswald H.E. Burmester. Cairo: Société d'Archéologie Copte.

History of the Patriarchs. 1948. = History of the Patriarchs of the Egyptian Church, Known as the History of the Holy Church, ed. and tr. Yassā 'Abd al-Masīh and 'Azīz Sūriyāl 'Ațiyya. Cairo: Société d'Archéologie Copte.

Hudūd al-älam. 1937. = Hudūd al-älam, 'The Regions of the World': A Persian Geography, 37 A.H.-982 A.D., tr. Vladimir Minorsky. 2nd ed., Oxford: Oxford University Press.

Ibn 'Abd al-Ḥakam, 'Abd Allāh. [1432/] 2011. Al-Mukhtaṣar al-kabìr, ed. Aḥmad b. 'Abd al-Karīm Najīb. Dublin: Markaz Najībawayh li-'l-Makhțūtāt wa-Khidmat al-Turāth.

Ibn 'Abd al-Ḥakam, 'Abd al-Raḥmān b. 'Abd Allāh. 1922. Futūḥ Miṣr wa-akhbāruhā, ed. Charles C. Torrey. New Haven: Yale University Press.

Ibn Abī Zayd al-Qayrawānī, 'Abd Allāh. 1999. Al-Nawādir wa-'l-zìyādāt 'alā mā fì alMudawwana min ghayrihā min al-ummahāt, ed. Muhammad Amīn Būkhubza. 15 vols., Beirut: Dār al-Gharb al-Islāmī.

Ibn al-A'rābī, Muḥammad b. Ziyād. [1405/] 1985. Asmā̄ khayl al-'arab wa-fursānihā, ed. Nūrī Ḥ. al-Qaysī and Ḥātim Ṣ. al-Ḍāmin. Baghdad: Maṭba'at al-Majma' al-'Ilmī al-'Irāqī.

Ibn 'Asākir, 'Alī b. al-Ḥasan. [1415-21/] 1995-200o. Ta’rīkh madīnat Dimashq wa-dhikr fậlihā wa-tasmiyat man hallahā min al-amāthil aw ijtāz bi-nawāḥ̄hā min wāridihā wa-ahlihā, ed. 'Umar b. Gharāma al-'Amrawī. 8 o vols., Beirut: Dār al-Fikr.

Ibn al-Athīr, 'Alī b. Muḥammad. [1357-69/] 1938-49 Al-Lubāb fì tahdhīb al-ansāb. 3 vols., Cairo: Maktabat al-Qudsī.

Ibn al-'Ațtāā, Muḥammad b. Aḥmad. 1983. Kitāb al-wathā̉iq wa-'l-sijillāt, ed. Pedro Chalmeta and Federico Corriente. Madrid: Academia Matritense del Notariado/ Instituto Hispano-Árabe de Cultura. 
Ibn Bassām, Muḥammad b. Aḥmad. 1968. Nihāyat al-rutba fi țalab al-hisisa, ed. Ḥussām al-Dīn al-Sāmarrāī. Baghdad: Maṭba'at al-Macārif.

Ibn Buṭlān, al-Mukhtār b. al-Ḥasan. [1393/] 1973. Risāla jāmi'a li-funūn nāfía fi shirā al-raqīq wa-taqlīb al-'abìd, ed. 'Abd al-Salām M. Hārūn. In Nawādir al-makhțūtāt, vol. 4. Cairo: al-Bābī al-Halabī.

Ibn Duqmāq, Ibrāhīm b. Muḥammad. 1893. Kitāb al-intiṣār li-wāsițat 'iqd al-amṣār, vols. 4-5, ed. Karl Vollers. Cairo: Imprimerie nationale.

Ibn al-Furāt, Muḥammad b. 'Abd al-Rahīm. 1942. Ta'rīkh al-duwal wa-'l-mulūk, vol. 7, ed. Qusțanțīn Ruzayq. Beirut: al-Maṭbaca al-Amīrkāniyya.

Ibn Ḥajar al-'Asqalānī, Aḥmad b. 'Alī. 1965-7. Tabṣīr al-muntabih bi-taḥrìr al-Mushtabih, ed. 'Alī M. al-Bajāwī and Muḥammad 'A. al-Najjār. 4 vols., Cairo: Al-Mu'assasa al-'Āmma li-'l-Ta'līf wa-'l-Tarjama wa-'l-Ṭibā'a wa-'l-Nashr.

Ibn Ḥawqal, Abū al-Qāsim b. 'Alī. 1938. Kitāb șūrat al-arḍ, ed. J.H. Kramers. 2 vols., Leiden: E.J. Brill.

Ibn al-Jallāb, 'Ubayd Allāh b. al-Ḥusayn. [1408/] 1987. Al-Tafrī' [fíal-figh al-mālikī], ed. Ḥusayn b. Sālim al-Dahmānī. 2 vols., Beirut: Dār al-Gharb al-Islāmī.

Ibn al-Jawzī, 'Abd al-Raḥmān b. 'Alī. [1415/] 1995. Al-Muntaẓam fì ta'rīkh al-mulūk wa'l-umam, ed. Muhammad 'A. 'Ațā and Mușțafā 'A. 'Ațā. 17 vols., Beirut: Dār al-Kutub al-'Ilmiyya.

Ibn al-Kindī, 'Umar b. Muḥammad. [1391/] 1971. Faḍā̇il Miṣr, ed. Ibrāhīm A. al-'Adawī and 'Alī M. 'Umar. Cairo: Maktabat Wahba.

Ibn Mākūlā, 'Alī b. Hibat Allāh. 1993-4. Al-Ikmālfìraf'irtiyābfìal-mu'talifwa-'l-mukhtalif fíal-asmā' wa-'l-kunāwa-'l-ansāb, ed. 'Abd al-Raḥmān b. Yahyyā al-Mu'allimī. 10 vols., Cairo: Dār al-Kitāb al-Islāmī.

Ibn Mughīth al-Ṭulayțulī, Aḥmad. 1994. Al-Muqni fì 'ilm al-shurūṭ, ed. Francisco J. Aguirre Sádaba. Madrid: Consejo Superior de Investigaciones Científicas.

Ibn Rushd, Muḥammad b. Aḥmad. [1404-7/] 1984-7. Al-Bayān wa-'l-taḥșil wa-'l-sharh wa-'l-tawjīh wa-'l-ta'lïl li-masā'il al-Mustakhraja, ed. Muhammad Hajjī et al. 20 vols., Beirut: Dār al-Gharb al-Islāmī.

Ibn al-Ṣābūnī Muḥammad b. 'Alī. [1377/] 1957. Takmilat Ikmāl al-ikmāl fì al-ansāb wa-'l-asmā' wa-'l-alqāb, ed. Mușțafā Jawwād. Baghdad: Mațba'at al-Majma' al-'Ilmī.

Ibn al-Sā'ì, 'Alī b. Anjab. 2015. Consorts of the Caliphs: Women and the Court of Baghdad, ed. Shawkat M. Toorawa, tr. the editors of the Library of Arabic Literature. London/ New York: New York University Press.

Ibn Taghrī Birdī, Yūsuf. 1929-72. Al-Nujūm al-zāhira fı̀ mulūk Miṣr wa-'l-Qāhira. 16 vols., Cairo: Maṭba'at Dār al-Kutub al-Mișriyya.

Ibn Wahb, 'Abd Allāh. 2004. Al-Muwatța' Kitāb al-qaḍ̄̄'fi al-buyū', ed. Miklos Muranyi. Beirut: Dār al-Gharb al-Islāmī.

Ibn Yūnus, 'Abd al-Raḥmān b. Aḥmad. [1421/] 200o. Ta’rīkh Ibn Yūnus al-Ṣadafì, ed. 'Abd al-Fattāḥ F. 'Abd al-Fattāḥ. 2 vols., Beirut: Dār al-Kutub al-'Ilmiyya. 
Al-Ișțakhrī, Ibrāhīm b. Muḥammad. 187o. Kitāb masālik al-mamālik, ed. Michael J. de Goeje. Leiden: E.J. Brill.

Al-Jazīrī, 'Alī b. Yahyā. 1998. Al-Maqșad al-maḥmūd fì talkhịs al-'uqūd, ed. Asunción Ferreras. Madrid: Consejo Superior de Investigaciones Científicas.

Kaminiates, John. 200o. The Capture of Thessaloniki, tr. David Frendo and Athanasios Fotiou. Perth: Australian Association for Byzantine Studies.

Al-Kawsaj, Isḥāq b. Manșūr. [1425/] 2004. Masā̉il Aḥmad b. Hanbal wa-Isḥāq b. Rāhūya. 10 vols., Medina: al-Jāmi'a al-Islāmiyya bi-'l-Madīna.

Al-Kindī, Muḥammad b. Yūsuf. 1912. Kitāb al-wulāt wa-kitāb al-quḍāt, ed. R. Guest., The Governors and Judges of Egypt. Leiden: E.J. Brill.

Al-Lakhmī, 'Alī b. Muḥammad. [1432/] 2011. Al-Tabṣira, ed. Aḥmad 'A. Najīb. 14 vols., Qatar: Wizārat al-Awqāf wa-'l-Shu'ūn al-Islāmiyya.

Mālik b. Anas. [1406/] 1985. Al-Muwațta', recension of Yahyā b. Yahyā al-Laythī, ed. Muḥammad F. 'Abd al-Bāqī. Repr. Beirut: Dār Iḥyā' al-Turāth al-'Arabī.

Al-Maqrīzì, Aḥmad b. 'Alī. [1411/] 1991. Kitāb al-muqaffā al-kabìr, ed. Muḥammad al-Ya'lāwī. 8 vols., Beirut: Dār al-Gharb al-Islāmī

Al-Maqrīzī, Ahmmad b. 'Alī. 2002-3. Al-Mawā'iz wa-'l-itibār fì dhikr al-khițaț wa-'l-āthār, ed. Ayman F. Sayyid. 5 vols., London: Al-Furqān Islamic Heritage Foundation.

Al-Muqaddasī, Muḥammad b. Aḥmad. 1877. Ahsan al-taqāsìm fì márifat al-aqālìm, ed. Michael J. de Goeje. Leiden: E.J. Brill.

Al-Mas'ūì̄i, 'Alī b. al-Ḥusayn. 1966-79. Murūj al-dhahab wa-ma'ādin al-jawhar, rev. ed. Charles Pellat. 7 vols., Beirut: Publications de l'Université Libanaise.

Al-Muzanī, Ismā̄īl b. Yahỵā. [1419/] 1994. Mukhtașar al-Muzanī fi furū'al-shāficiyya, ed. Muhạmmad 'A. Shāhīn. Beirut: Dār al-Kutub al-'Ilmiyya.

Nāṣir-i Khusraw. 1986. Book of Travels (Safarnāma), tr. W.M. Thackston, Jr. Albany: State University of New York Press.

Al-Nuwayrī, Aḥmad b. 'Abd al-Wahhāb. 1923-97. Nihāyat al-arab fí funūn al-adab. 33 vols., Cairo: Mațba'at Dār al-Kutub al-Mișriyya (vols. 1-18 and 32-3)/al-Hay’a al-Mișriyya al-'Āmma li-'l-Kitāb (vols. 19-31).

Al-Qalqashandī, Aḥmad b. 'Alī. [1331-38/] 1913-16. Șubḥ al-a šshāfí șinā'at al-inshā’, ed. Muhammad Q. al-Baqlī. 14 vols., Cairo: al-Mațba'a al-Amīriyya.

Al-Ṣafadī, Khalīl b. Aybak. 200o. Al-Wāfi bi-'l-wafayāt, ed. Aḥmad al-Arna'ūṭ and Turkī Mușțafā. 29 vols., Beirut: Dār Ihyyā’ wa-'l-Turāth al-'Arabī.

Saḥnūn, 'Abd al-Salām b. Sa'̄ìd. [1323/] 1905. Al-Mudawwana al-kubrā. 16 vols., Cairo: Mațba'at al-Sa'āda.

Al-Sam‘ānī, 'Abd al-Karīm b. Muḥammad. [1408/] 1988. Al-Ansāb, ed. 'Abd Allāh 'U. al-Bārūdī. 5 vols., Beirut: Dār al-Jinān.

Al-Sarakhsī, Muḥammad b. Aḥmad. N.d. Kitāb al-mabsūṭ. Repr. Beirut: Dār al-Márifa. Al-Shāfi'ī, Muhammad b. Idrīs. [1422/] 2001. Kitāb al-umm, ed. Rif'at F. ‘Abd al-Muțțalib. 11 vols., al-Manșūra: Dār al-Wafā̄. 
Al-Shaybānī, Muḥammad b. al-Ḥasan. 2012. Kitāb al-aṣl, ed. Mehmet Boynukalın. Qatar: Wizārat al-Awqāf/Beirut: Dār Ibn Ḥazm.

Al-Shayzarī, 'Abd al-Raḥmān b. Nașr. [1365/] 1946. Nihāyat al-rutba fí țalab al-ḥisba, ed. al-Bāz al-'Arīnī. Cairo: Mațba'at Lajnat al-Ta'līf wa-'l-Tarjama wa-'l-Nashr.

Al-Ṭabarī, Muhammad b. Jarīr. 1879-19o1. Ta’rīkh al-rusulwa-'l-mulūk, ed. M.J. de Goeje et al. 5 vols. with 13 sub-vols. and supplement, Leiden: E.J. Brill.

Al-Ṭabarī, Muhammad b. Jarīr. [1420/] 1999. Ikhtilāf al-fuqahā’, no ed. Beirut: Dār alKutub al-'Ilmiyya.

Al-Ṭaḥāwī, Aḥmad b. Muḥammad. 1972. Al-Shurūṭ al-kabìr: Kitāb al-buyū', ed. Jeanette A. Wakin, The Function of Documents in Islamic Law: The Chapters on Sales from Tahāwì’s Kitāb al-shurūṭ al-kabīr. Albany: State University of New York Press.

Al-Ṭahāwī, Aḥmad b. Muhammad. [1393/] 1974. Al-Shurūṭ al-ṣaghīr, ed. Ruhi Özcan. 2 vols., Baghdad: Mațba'at al-'̄̄nī.

Al-Ṭahāwī, Aḥmad b. Muḥammad. [1416/] 1995. Mukhtașar Ikhtilāf al-ulamā’a abr. Aḥmad b. 'Alī al-Jașṣāṣ, ed. 'Abd Allāh N. Aḥmad. 5 vols., Beirut: Dār al-Bashāiir al-Islāmiyya.

Al-Tanūkhī, al-Muḥassan b. 'Alī. [1397/] 1978. Al-Faraj ba'd al-shidda, ed. 'Abbūd al-Shāljī. 5 vols., Beirut: Dār Șādir.

Al-Usyūṭī, Muḥammad b. Aḥmad. 1955. Jawāhir al-'uqūd wa-mu'in al-quḍāt wa-'lmuwaqqi'in wa-'l-shuhūd, ed. Muḥammad H. al-Fīqī. 2 vols., Cairo: Mațba'at alSunna al-Muhammadiyya.

\section{Secondary Literature}

Ali, Kecia. 2010. Marriage and Slavery in Early Islam. Cambridge, MA: Harvard University Press.

Barker, Hannah. 2014. Egyptian and Italian Merchants in the Black Sea Slave Trade, 1260-1500. PhD dissertation: Columbia University.

Barker, Hannah. 2016. Purchasing a Slave in Fourteenth-Century Cairo: Ibn al-Akfānīs Book of Observation and Inspection in the Examination of Slaves. Mamluk Studies Review 19: 1-23.

Braude, Benjamin. 2002. Cham et Noé: Race, esclavage et exégèse entre islam, judaïsme et christianisme. Annales: Histoire, Sciences Sociales 57/1: 93-125.

Bruning, Jelle. Forthcoming. Household Slavery in Arabic Documents up to ca. AH 183/ AD 8oo.

Campagnolo-Pothitou, Maria. 1995. Les échanges de prisonniers entre Byzance et l'Islam aux IX ${ }^{\mathrm{e}}$ et $\mathrm{X}^{\mathrm{e}}$ siècles. Journal of Oriental and African Studies 7: 1-55.

Caswell, Fuad M. 2011. The Slave Girls of Baghdad: The Qiyān in the Early Abbasid Era. London/New York: I.B. Tauris.

Christides, Vassilios. 1984. The Conquest of Crete by the Arabs (ca. 824): A Turning Point in the Struggle Between Byzantium and Islam. Athens: Akadēmia Athēnōn. 
Clackson, Sarah J. 1994. The Michaelides Manuscript Collection. Zeitschrift für Papyrologie und Epigraphik 100: 223-6.

De la Puente, Cristina. 2008. Slaves in al-Andalus through Mālikī Wathā̉iq Works (4th6th Centuries H / 1oth-12th Centuries CE). Annales islamologiques 42: 187-212.

De la Puente, Cristina. 2010. Mano de obra esclava en Al-Andalus. In Minas y esclavos en la Península Ibérica y el Maghreb en la Edad Media, ed. Ana Echevarría and Cristina de la Puente in Espacio, Tiempo y Forma, ser. 3: Historia medieval 23: 135-47.

De la Puente, Cristina. 2013. Free Fathers, Slave Mothers and their Children: A Contribution to the Study of Family Structures in al-Andalus. Imago Temporis: Medium Aevum 7: 27-44.

Den Heijer, Johannes. 1989. Mawhūb Ibn Manșūr Ibn Mufarriğ et l'historiographie coptoarabe: Étude sur la composition de "l'Histoire des Patriarches d'Alexandrie". Leuven: Peeters.

Denoix, Sylvie. 1992. Décrire le Caire: Fusțāț-Mișr d'après Ibn Duqmāq et Maqrīzī: L'histoire d'une partie de la ville du Caire d'après deux historiens égyptiens des $X I V^{e}-X V^{e}$ siècles. Cairo: IFAo.

Diem, Werner. 1993. Philologisches zu den Khalili-Papyri. Wiener Zeitschrift für die Kunde des Morgenlandes 83: 39-81.

Diem, Werner. 2012. Philologisches zu arabischen Dokumenten, II: Dokumente aus der Sammlung der Egyptian Library in Kairo. Zeitschrift für arabische Linguistik 56: 27-78.

Dirbas, Hekmat. 2019. Naming of Slave-Girls in Arabic: A Survey of Medieval and Modern Sources. Zeitschrift für arabische Linguistik 69: 26-38.

Dozy, Reinhart. 1927. Supplément aux dictionnaires arabes, 2nd ed. 2 vols., Leiden: E.J. Brill/Paris: Maisonneuve.

Ducène, Jean-Charles. 2015. Une nouvelle source arabe sur l'océan Indien au X $\mathrm{X}^{\mathrm{e}}$ siècle: Le Șaḥ̄h min ahbār al-biḥār wa-'ağàibihā d'Abū 'Imrān Mūsā ibn Rabāh al-Awsī al-Sīrāfì. Afriques 6, https://journals.openedition.org/afriques/1746.

Franz, Kurt. 2017. Slavery in Islam: Legal Norms and Social Practice. In Slavery and the Slave Trade in the Eastern Mediterranean (c. 1000-1500 CE), ed. Reuven Amitai and Christoph Cluse. Turnhout: Brepols: 51-141.

Fynn-Paul,Jeffrey. 2009. Empire, Monotheism, and Slavery in the Greater Mediterranean Region from Antiquity to the Early Modern Era. Past and Present 205: 3-40.

Gaiser, Adam. 2013. Slaves and Silver across the Strait of Gibraltar: Politics and Trade between Umayyad Iberia and Khārijite North Africa. Medieval Encounters 19: 41-70.

Goitein, Shelomo D. 1967-93. A Mediterranean Society: The Jewish Communities of the Arab World as Portrayed in the Documents of the Cairo Geniza. 6 vols., Berkeley: University of California Press.

Goldberg, Jessica L. 2012. Trade and Institutions in the Medieval Mediterranean: The Geniza Merchants and their Business World. Cambridge: Cambridge University Press. 
Goldenberg, David M. 2003. The Curse of Ham: Race and Slavery in Early Judaism, Christianity, and Islam. Princeton/Oxford: Princeton University Press.

Gordon, Matthew S. 2009. Yearning and Disquiet: Al-Jāḥiz and the Risālat al-Qiyān. In Al-Jāhiz: A Muslim Humanist for Our Time, ed. Arnim Heinemann et al. Würzburg: Ergon Verlag: 253-68.

Gordon, Matthew S. 2017. Introduction: Producing Songs and Sons. In Gordon and Hain 2017: 1-10.

Gordon, Matthew S. and Kathryn A. Hain, ed. 2017. Concubines and Courtesans: Women and Slavery in Islamic History. New York: Oxford University Press, 2017.

Grob, Eva Mira. 2010. Documentary Arabic Private and Business Letters on Papyrus: Form and Function, Content and Context. Berlin/New York: Walter de Gruyter.

Grob, Eva Mira. 2013. A Catalogue of Dating Criteria for Undated Arabic Papyri with 'Cursive' Features. In Documents et histoire: Islam, VII $-X V I^{e}$ s. Actes des journées d'études Musée du Louvre/EPHE, mai 2008, ed. Anne Regourd. Geneva: Librairie Droz: $115-35$.

Halm, Heinz. 1998. Der nubische Baqț. In Egypt and Syria in the Fatimid, Ayyubid and Mamluk Eras, vol. 2: Proceedings of the 4th and 5th International Colloquium Organized at the Katholieke Universiteit Leuven in May 1995 and 1996, ed. U. Vermeulen and D. de Smet. Leuven: Uitgeverij Peeters: 63-103.

Harper, Kyle. 2011. Slavery in the Late Roman World, AD 275-425. Cambridge: Cambridge University Press.

Harding, Gerald W.L. 1971. An Index and Concordance of Pre-Islamic Arabian Names and Inscriptions. Toronto: Toronto University Press.

Hinds, Martin and Hamdi Sakkout. 1981. A Letter from the Governor of Egypt to the King of Nubia and Muqurra Concerning Egyptian-Nubian Relations in 141/758. In Studia Arabica \& Islamica: Festschrift for Ihsān 'Abbās on His Sixtieth Birthday, ed. Wadād al-Qāḍī. Beirut: American University of Beirut: 209-29.

Hopkins, Simon. 1984. Studies in the Grammar of Early Arabic: Based upon Papyri Datable to Before 300 A.H./912 A.D. Oxford: Oxford University Press.

Jankowiak, Marek. 2015. Wer brachte im 10. Jahrhundert die Dirhems in die polnischen Gebiete und warum? In Fernhändler, Dynasten, Kleriker: Die piatische Herrschaft in kontinentalen Beziehungsgeflechten vom 10. bis zum frühen 13. Jahrhundert, ed. Dariusz Adamczyk and Norbert Kersken. Wiesbaden: Harrassowitz Verlag: 41-54. Jankowiak, Marek. 2017. What Does the Slave Trade in the Saqaliba Tell Us about Early Islamic Slavery? International Journal of Middle East Studies 49/1: 169-72.

Johansen, Baber. 1996. The Valorization of the Human Body in Muslim Sunni Law. Interdisciplinary Journal of Middle Eastern Studies 4: 71-112.

Johansen, Baber. 1997. Formes de langage et fonctions publiques: Stéréotypes, témoins et offices dans la preuve par l'écrit en droit musulman. Arabica 44/3: 333-76. 
Kilpatrick, Hillary. 1991. Women as Poets and Chattels: Abū l-Faraj al-Iṣbahānī’s al-Imăa al-šawāir. Quaderni di studi arabi 9: 161-76.

Kubiak, Władysław B. 1987. Al-Fustat: Its Foundation and Early Urban Development. Cairo: The American University in Cairo Press.

Kubiak, Władysław B., and George T. Scanlon. 1989. Fusțāt Expedition Final Report, vol. 2: Fusțāt-C. Winona Lake: Eisenbrauns.

Lane, Edward W. 1863-93. An Arabic-English Lexicon Derived from the Best and Most Copious Eastern Sources. 8 vols., London: Williams and Norgate.

Leiser, Gary. 1981. Hanbalism in Egypt before the Mamlûks. Studia Islamica 54: 155-81.

Levy-Rubin, Milka. 2011. Non-Muslims in the Early Islamic Empire: From Surrender to Coexistence. New York: Cambridge University Press.

Lewis, Bernard. 199o. Race and Slavery in the Middle East: An Historical Enquiry. Oxford: Oxford University Press.

McCormick, Michael. 2001. Origins of the European Economy: Communications and Commerce A.D. 300-900. Cambridge: Cambridge University Press.

McCormick, Michael. 2012. Movements and Markets in the First Millennium: Information, Containers, and Shipwrecks. In Trade and Markets in Byzantium, ed. Cécile Morrisson. Washington, DC: Harvard University Press: 51-98.

Müller, Christian. 2013. Der Kadi und seine Zeugen: Studie der mamlukischen Haram-Dokumente aus Jerusalem. Wiesbaden: Harrassowitz Verlag.

Müller, Christian. 2018. The Power of the Pen: Cadis and Their Archives. In Manuscripts and Archives: Comparative Views on Record-Keeping, ed. Alessandro Bausi et al. Berlin/Boston: Walter de Gruyter: 361-85.

Müller, Hans. 1980. Die Kunst des Sklavenkaufes, nach arabischen, persischen und türkischen Ratgebern vom 10. bis zum 18. Jahrhundert. Freiburg i. B.: Klaus Schwarz Verlag.

Nyazee, Imran A.K. 1999. Islamic Law of Business Organization:Partnerships. Islamabad: International Institute of Islamic Thought.

Perry, Craig. 2014. The Daily Life of Slaves and the Global Reach of Slavery, 969-125o CE. PhD dissertation: Emory University.

Perry, Craig. 2017. Historicizing Slavery in the Medieval Islamic World. International Journal of Middle East Studies 49/1: 133-38.

Pétré-Grenouilleau, Olivier. 2004. Les traites négrières: Essai d'histoire globale. Paris: Éditions Gallimard.

Power, Timothy. 2009. The Origin and Development of the Sudanese Ports ('Aidhâb, Bâdi', Souakin) in the Early Islamic Period. Chroniques yéménites 15: 92-110. Consulted online: http://journals.openedition.org/cy/1685; DOI: 10.400o/cy.1685.

Power, Timothy. 2012. The Red Sea from Byzantium to the Caliphate, AD 500-1000. Cairo: American University in Cairo Press. 
Rāgiib, Yūsuf. 1993. Les marchés aux esclaves en terre d'Islam. In Mercati e mercanti nell'alto medioevo: L'area euroasiatica e l'area mediterranea. 23-19 aprile 1992, no ed., Spoleto: Centro Italiano di Studi Sull'Alto Medioevo: 721-66.

Rāgiib, Yūsuf. 1996. Les esclaves publics aux premiers siècles de l'Islam. In Figures de l'esclave au Moyen-Âge et dans le monde moderne. Actes de la table ronde organisée les 27 et 28 octobre 1992 par le Centre d'Histoire Sociale et Culturelle de l'Occident de l'Université de Paris-X Nanterre, ed. Henri Bresc. Paris: L'Harmattan: 7-3o.

Rāgib, Yūsuf. 1997. La parole, le geste et l'écrit dans l'acte de vente. Arabica 44/3: 407-22. Rāgib, Yūsuf. 2002-6. Actes de vente d'esclaves et d'animaux. 2 vols., Cairo: IfAO.

Rāgib, Yūsuf. 2013. Esclaves et affranchis trahis par leur nom dans les arts de l'Islam médiéval. In Les non-dits du nom: Onomastique et documents en terre d'Islam. Mélanges offerts à Jacqueline Sublet, ed. Christian Müller and Muriel RoilandRouabah. Beirut: Presses de l'IFPO: 247-301. Consulted online: http://books.open edition.org.ifpo/5764.

Rosenthal, Franz. 2011 [orig. 1956]. Humor in Early Islam, with intr. Geert Jan van Gelder. Leiden/Boston: Brill.

Rotman, Youval. 2009. Byzantine Slavery and the Mediterranean World, tr. Jane Marie Todd. Cambridge, MA/London: Harvard University Press.

Rotman, Youval. 2012. Captif ou esclave? Entre marché d'esclaves et marché de captifs en Méditerranée médiévale. In Les esclaves en Méditerranée: Espaces et dynamiques économiques, ed. Fabienne P. Guillén and Salah Trabelsi. Madrid: Casa de Velázquez: 25-46.

Rotter, Gernot. 1967. Die Stellung des Negers in der islamisch-arabischen Gesellschaft bis zum XVI. Jahrhundert. PhD thesis: Friedrich-Wilhelms-Universität.

Ruffini, Giovanni R. 2012. Medieval Nubia: A Social History. Oxford: Oxford University Press.

Ryckmans, Gonzague. 1934. Les nom propres sud-sémitiques. 2 vols., Louvain: Bureau du Muséon.

Schacht, Joseph. 1964. An Introduction to Islamic Law. Oxford: Clarendon Press.

Schneider, Irene. 1999. Kinderverkauf und Schuldknechtschaft: Untersuchungen zur frühen Phase des islamischen Rechts. Stuttgart: Kommissionsverlag Franz Steiner.

Sijpesteijn, Petra M. 2014. Making the Private Public: A Delivery of Palestinian Oil in Third/Ninth-Century Egypt. Studia Orientalia Electronica 2: 74-91. https://journal.fi/ store/article/view/41377.

Spaulding,Jay. 1995. Medieval Christian Nubia and the Islamic World:A Reconsideration of the Baqt Treaty. The International Journal of African Historical Studies 28/3: 577-94. Sundelin, Lennart. 2004. Introduction: Papyrology and the Study of Early Islamic Egypt. In Papyrology and the History of Early Islamic Egypt, ed. Petra M. Sijpesteijn and Lennart Sundelin. Leiden/Boston: Brill: 1-19. 
Tyan, Émile. 1945. Le notariat et le régime de la preuve par écrit dans la pratique du droit musulman. Lyon: Université de Lyon.

Udovitch, Abraham L. 1970. Partnership and Profit in Medieval Islam (Princeton, NJ: Princeton University Press.

Van Gelder, Geert Jan. 2004. Slave-Girl Lost and Regained: Transformations of a Story. Marvels \& Tales: Journal of Fairy-Tale Studies 18/2: 201-17.

Vantini, Giovanni. 1975. Oriental Sources Concerning Nubia. Heidelberg: Heidelberger Akademie der Wissenschaften.

Wakin, Jeanette A. 1972. The Function of Documents in Islamic Law: The Chapters on Sales from Tahâawì̀s Kitāb al-shurūṭ al-kabīr. Albany: State University of New York Press.

Wichard,Johannes C.1995.ZwischenMarktundMoschee:WirtschaftlicheBedürfnisseund religiöse Anforderungen im frühen islamischen Vertragsrecht. Paderborn/Munich/ Vienna/Zurich: Ferdinand Schöningh.

Wright, Thomas. 1848. Early Travels in Palestine. London: Henry G. Bohn.

Wright, William. 1896-8. Arabic Grammar, 3rd ed. 2 vols., Cambridge: Cambridge University Press.

Younes, Khaled M. 2013. Joy and Sorrow in Early Muslim Egypt. Arabic Papyrus Letters: Text and Content. PhD thesis: Leiden University. 
P. CtYBR inv. 2667

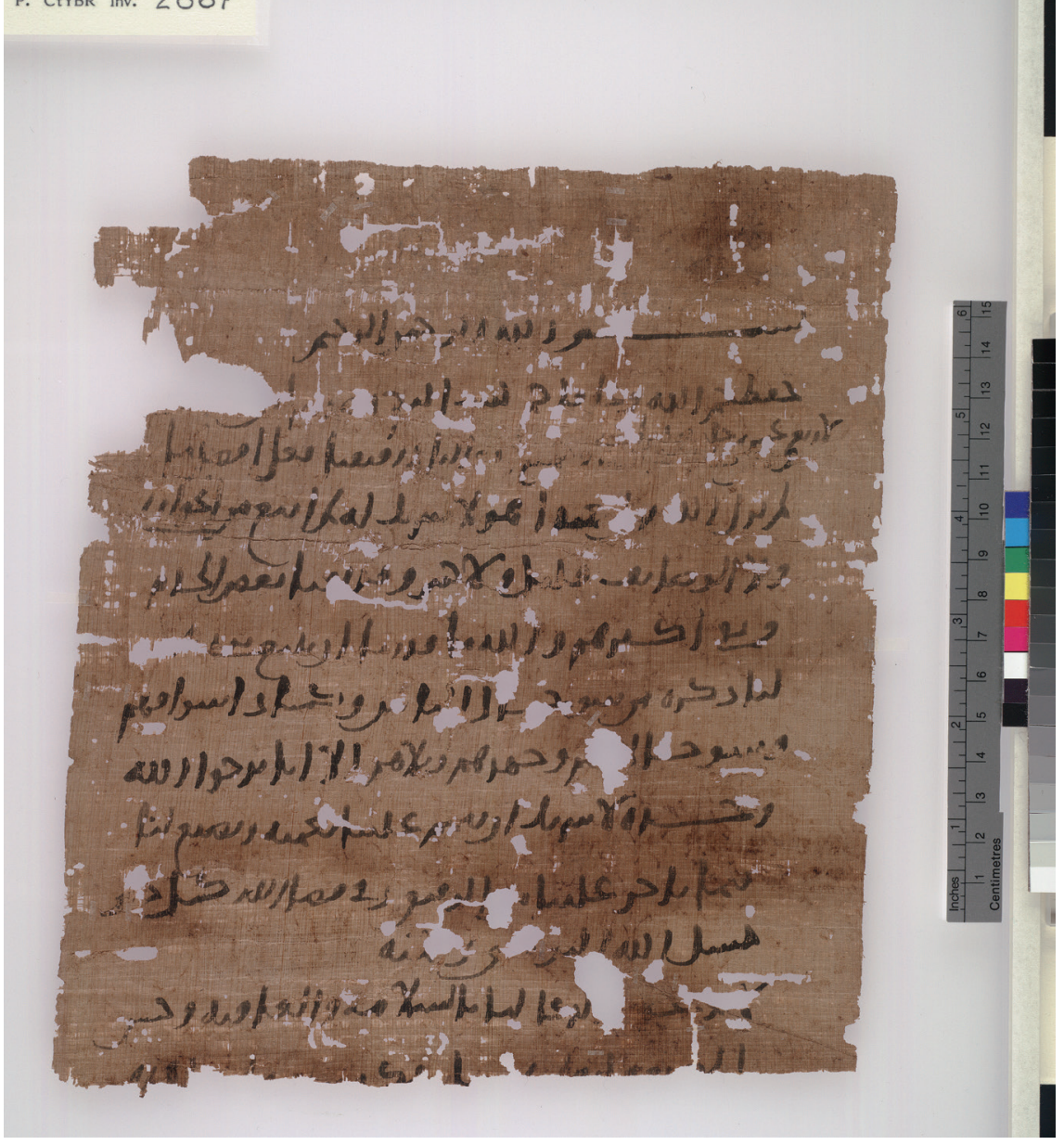

PLATE I P.CtYBR inv. 2667, recto 


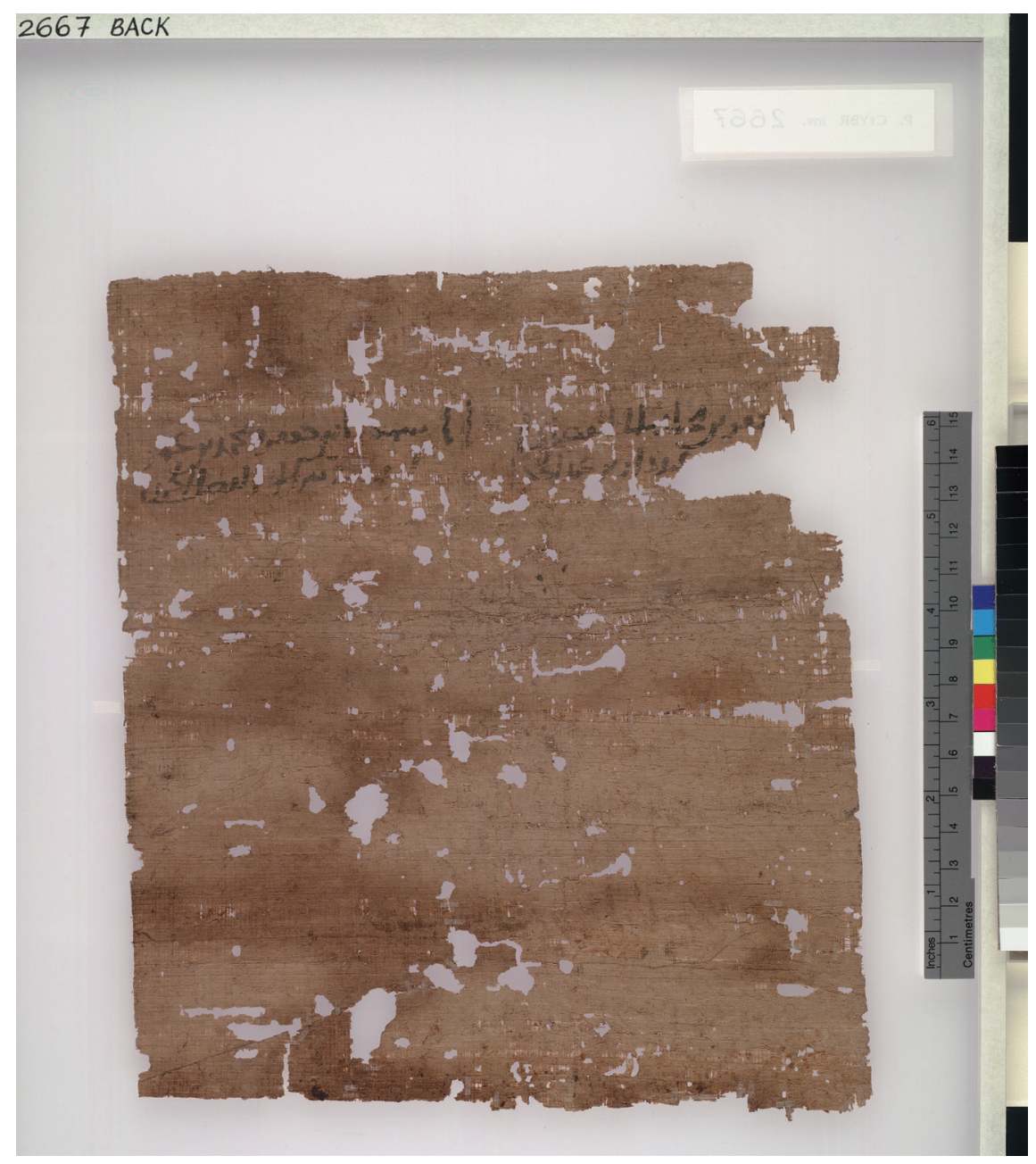

PLATE II P.CtYBR inv. 2667, verso 


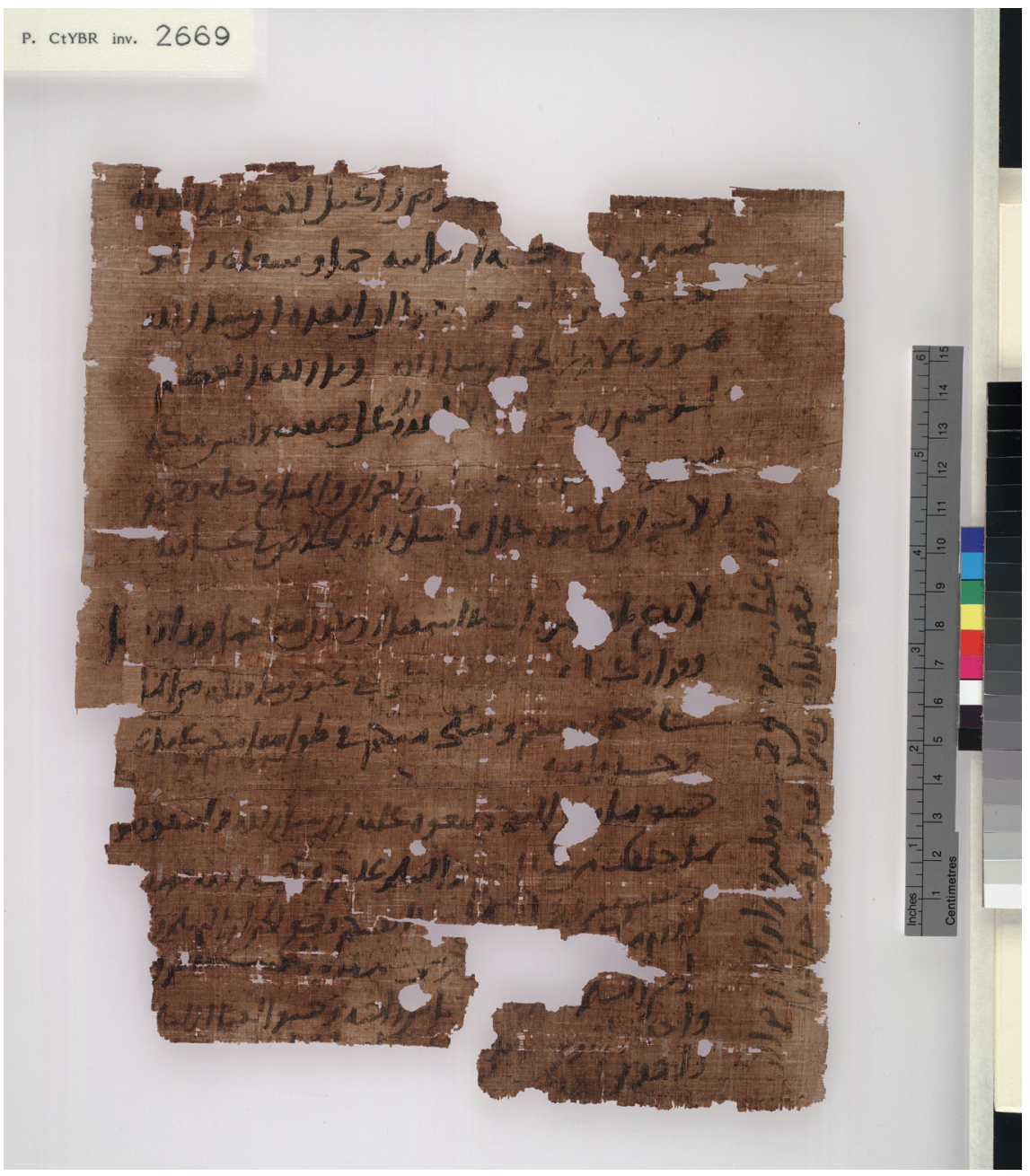

PLATE III P.CtYBR inv. 2669, recto 


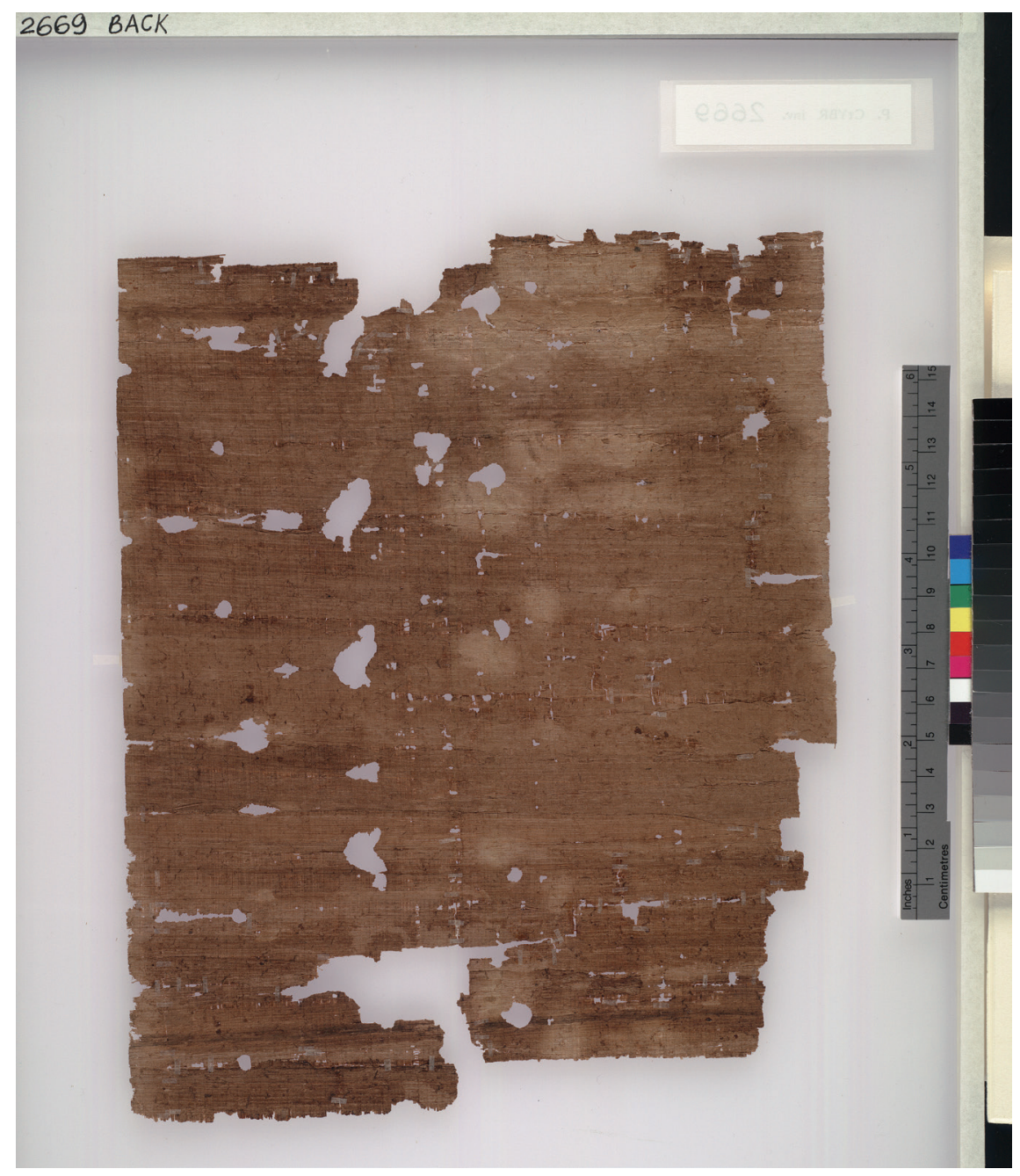

PLATE IV P.CtYBR inv. 2669, verso 


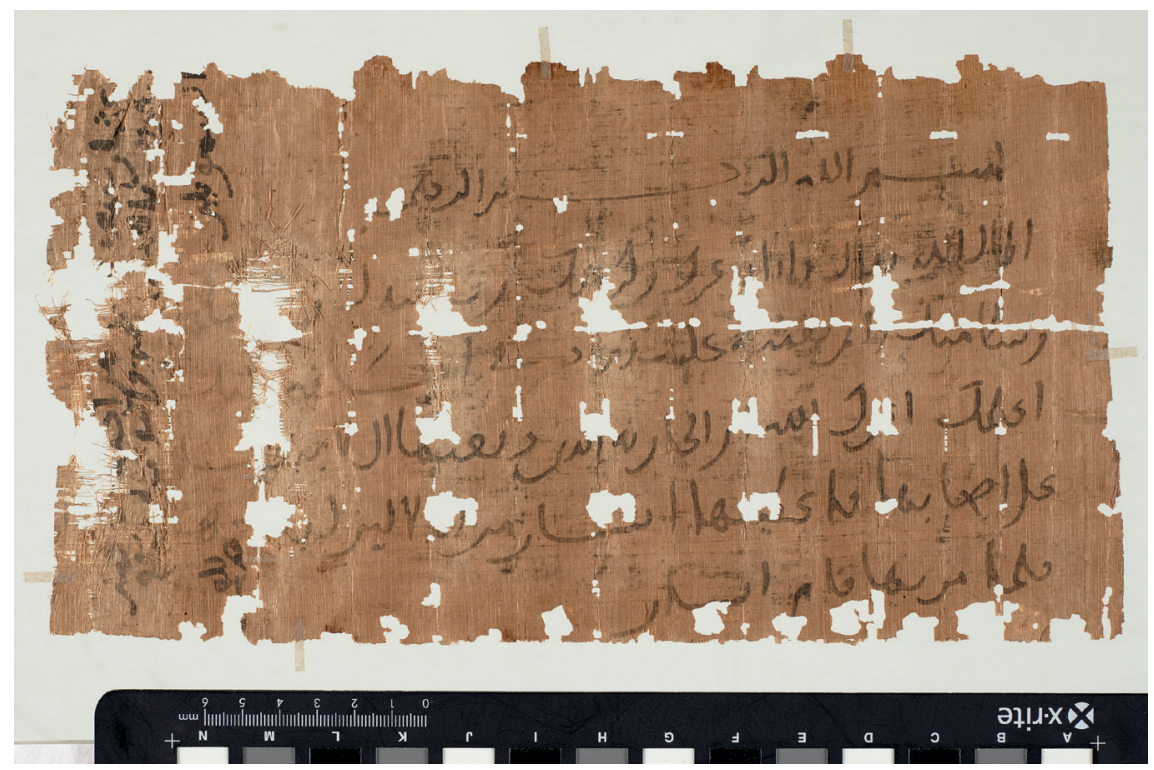

PLATE V P.Ryl. inv. B III 10 (A), copyright of the University of Manchester 


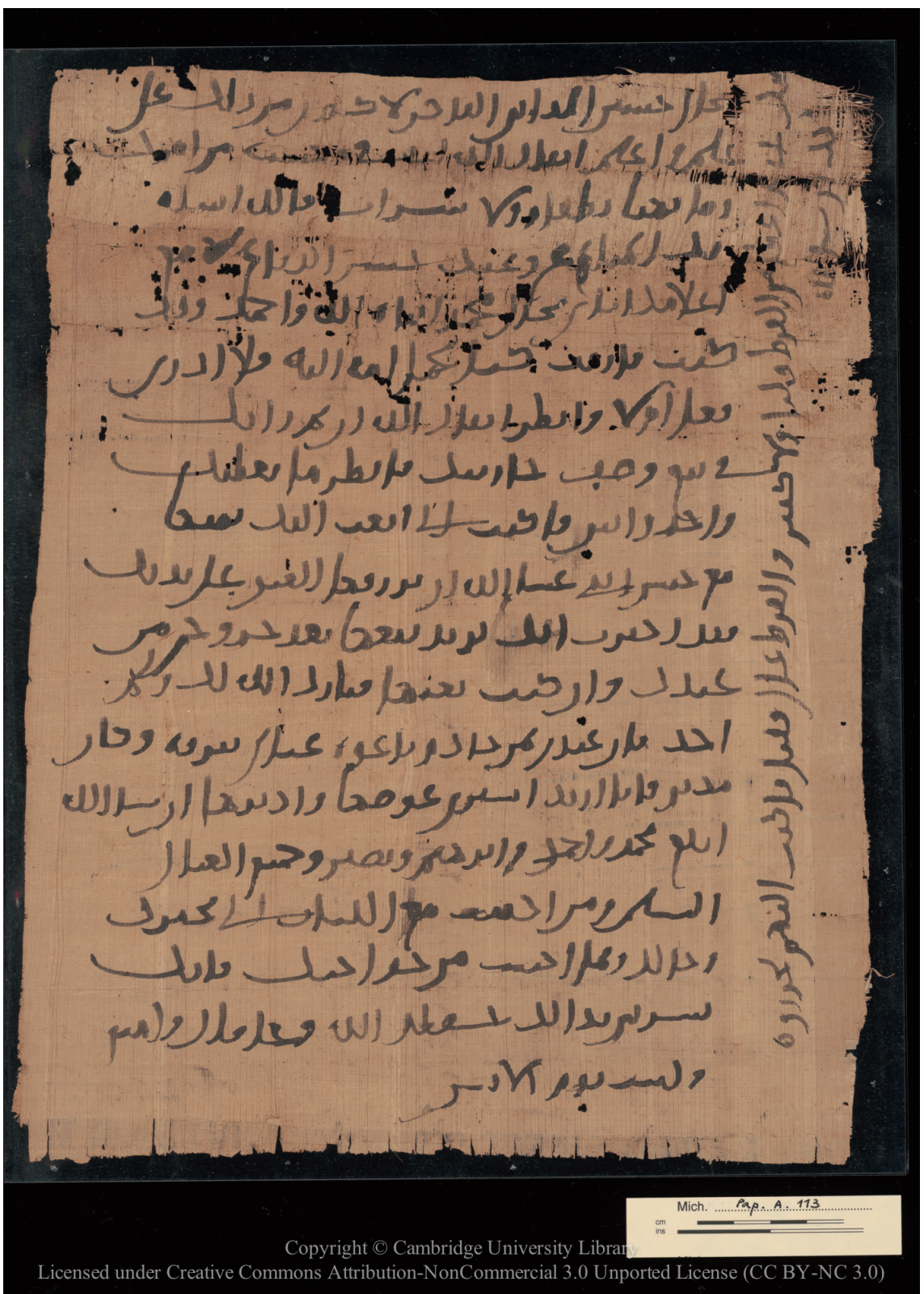

PlAte VI P.Cam. inv. Mich.Pap.A.113, copyright of Cambridge University 


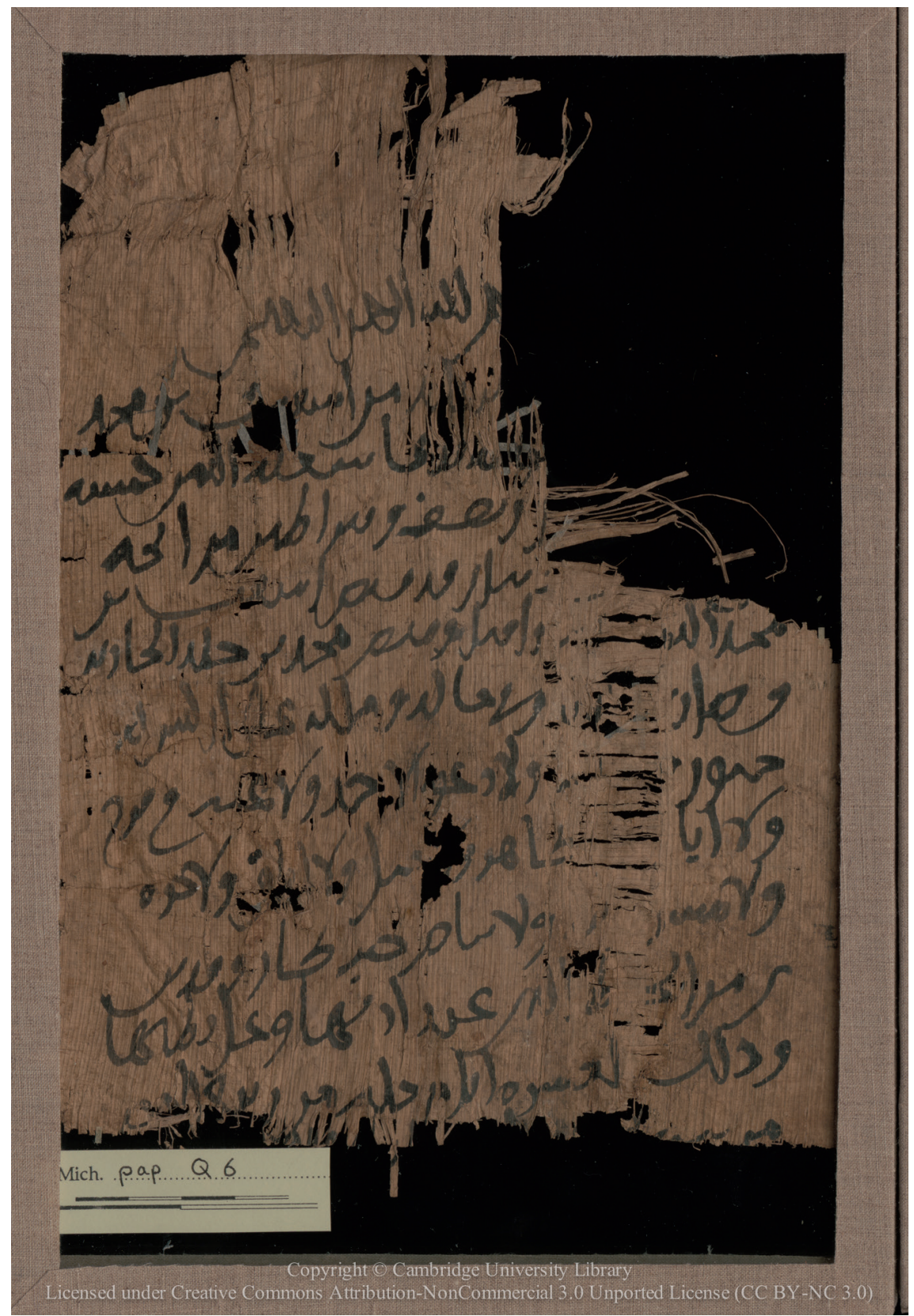

PLATE VII P.Cam. inv. Mich.Pap.Q.6, copyright of Cambridge University 